\title{
DEVELOPMENT AND HEREDITY IN HETEROGENIC TELEOST HYBRIDS
}

\author{
H. H. NEWMAN
}

From the Marine Biological Laboratory, Woods Hole, Mass., and the Hull Zoological Laboratory, University of Chicago

ELEVEN FIGCRES

\section{CONTENTS}

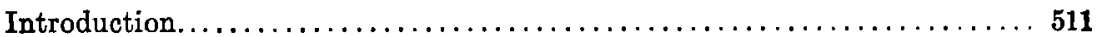

Literature on heterogenic teleost hybrids...................... 513

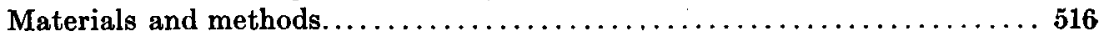

Crosses with the eggs of Fundulus heteroclitus.................... 519

Crosses with the eggs of Fundulus diaphanus..................... 528

Crosses with the eggs of Fundulus majalis...................... 529

Crosses with the eggs of Cyprinodon variegatus. . . . . . . . . . . . . . . 530

Crosses with the eggs of Gasterosteus aculeatus.................... 532

Crosses with the eggs of Apeltes quadracus........................ 537

Crosses with the eggs of Menidia menidia notata .................. 541

Crosses with the eggs of Scomber scombrus...................... 547

Crosses with the eggs of Stenotomus chrysops.................... 548

Crosses with the eggs of Tautogolabrus adspersus................... 551

Crosses with the eggs of Tautoga onitis......................... 554

Discussion of data....................................... 555

Success of development and systematic relationship...............555

Factors governing success in the development of Teleost hybrids...... 558

Factors governing differences in success of reciprocal crosses....... 562

Inheritance in heterogenic crosses. . . . . . . . . . . . . . . . . . . 563

Hybridization and the occurrence of monsters . . . . . . . . . . . 567

Developmental blocks in heterogenic crosses.................. 568

Auto-differentiation and de-differentiation.................. 572

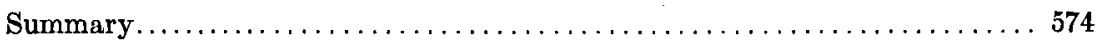

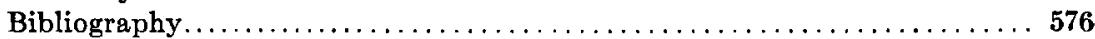

\section{INTRODUCTION}

During the months of June and July, 1914, I undertook the task of cross breeding all of the Teleost fish that could be found spawning during these months in the vicinity of Woods Hole. The excellent facilities afforded by the new laboratory building, 
together with the opportunity of examining most of the fish brought in daily from the traps, made it possible for me to obtain ninety-three different crosses, seventy-eight of which are heterogenic (between different orders or families) and fifteen homogenic (between different genera of the same family or different species of the same genus). Any distinction that may be made between homogenic and heterogenic crosses must be based on an arbitrary line of demarkation. Loeb believes that there is a real difference in the character of development and heredity in the two types of hybrids which he calls homogeneous and heterogeneous, but he does not define the limits of the two types. It will be useful to consider inter-phylum, inter-class, inter-order, and inter-family crosses as heterogenic; and inter-generic, inter-specific, and inter-varietal as homogenic. Obviously there exist different grades of heterogeneity and homogeneity within the two subdivisions, and these grades will receive attention when matters of success in development and of heredity are under consideration.

In order somewhat to limit the size and scope of the present paper I have decided to deal with the seventy-eight heterogenic crosses and to leave the homogenic crosses for later communication. It was my intention to make at least two experiments with every cross but in a few cases good eggs were obtained only once and it was not possible to repeat the experiment. In most of the experiments I had the coöperation of Mr. Austin P. Larabee, whose assistance greatly facilitated the work. The majority of the observations described in this paper have been confirmed by him although his chief interest lies in the study of the behavior of the chromatin in a number of the more favorable heterogenic crosses here dealt with. In view of the fact that Mr. Larrabee is to deal in detail with the cytological side of this subject, I shall make no statements concerning this phase of the work, but shall refer only incidentally to the cytological results of other authors.

The purpose of this paper is to present a general survey of heterogenic hybridization in Teleosts, to discuss the principal problems involved and to point out the particular parts of the 
field which have seemed to me most worthy of detailed study. The one salient impression that I have carried away from my survey of this relatively extensive field is the impression of its richness. It is a new and promising line of work that offers much to the investigator who is willing to study intensively some of the more favorable crosses here dealt with only in outline.

\section{LITERATURE ON HETEROGENIC TELEOST HYBRIDS}

Comparatively few writers have dealt with fish hybrids and of these the majority have bred together rather closely related species. Of those who have described the results of inter-crossing different families or orders we may mention Appellöf, Moenkhaus, J. Loeb, Günther and Paula Hertwig, and Morris.

Appellöf ('94) is the pioneer in this field. His results and conclusions have been referred to in another recent paper (Newman '14) and only a brief statement of the crosses made by him and of their developmental success need be made. $\mathrm{He}$ produced but one cross between two orders: Labrus rupestris क (family I abridae, order Haplomi) $\times$ Gadus morrhua or (family Gadidae, order Acanthopterygii). In this cross none of the embryos went further than an early germ-ring stage with a small embryonic shield. A cross between two families of the same order was made reciprocally between Gadus morrhua (family Gadidae) and Pleuronectes platessa (family Pleuronectidae). In the cross Pleuronectes $q \times$ Gadus $\sigma^{r}$ the eggs developed normally up to early germ-ring stages but no embryonic differentiation occurred. The reciprocal cross gave entirely negative results, none of the eggs being fertilized. These two are the only heterogenic crosses that were made by Appellöf, if we use the term heterogenic as previously defined. It will be noted that in neither cross did the development proceed beyond an early gastrulation stage. Appellöf lays great emphasis on the idea that gastrulation is the most important developmental block in the embryonic life of hybrids.

Moenkhaus in 1904 described the reciprocal hybrids between Fundulus heteroclitus (order Haplomi) and Menidia notata 
(order Acanthopterygii). He was not primarily interested in determining the success in development of these hybrids and therefore did not seriously attempt to rear them. His account indicates that he was unable to get the Fundulus egg hybrid to develop beyond the period of gastrulation and that the Menidia egg hybrid would not go beyond an early germ-ring stage. It was of much import to note that both the Fundulus and the Menidia types of chromosomes retained their individuality as far as late cleavage stages. In a subsequent paper published in 1911, Moenkhaus gives an account of a fairly large number of Teleost hybrids made during June and July at Woods Hole. In all twenty-eight distinct crosses were described, twentythree of which are heterogenic. Eight of Moenkhaus' crosses are duplicates of those that I have made and fifteen of them I was unable to repeat. In general it may be said that Moenkhaus was more interested in comparing the rate of development, especially during early cleavage, in pure and in hybrid strains, than in determining their degree of success in development. No attention at all was given by him to the inheritance of paternal and maternal characters. In a few of the experiments that he was especially interested in he followed development as far as it went, but in the majority of the experiments the account closes when there has appeared a definite difference in the rate of development of the pure and hybrid stains. Comparisons between Moenkhaus' crosses and my own and detailed comments on resemblances and differences will be made in connection with each cross. It may be said in advance that Moenkhaus did not get any of his heterogenic crosses to develop very far. This failure to get any advanced embryos or larvae is rather striking in view of the quite opposite results of many of my own experiments.

A paper on "Heredity in heterogeneous hybrids" was published in 1912 by $\mathrm{J}$. Loeb. In this the author deals with various Echinoderm hybrids and the following Teleost crosses: Fundulus heteroclitus $\circ \times$ by Menidia sp. $\sigma^{7}$; Tautogolabrus adspersus $\$ \times$ Stenotomus chrysops $\sigma^{7}$. It was also mentioned incidentally that a cross between Menidia sp. $q \times \mathrm{F}$. heteroclitus $\sigma^{x}$ 
had been made. 'The conclusion that Loeb reaches is that development in heterogenic hybrids is essentially parthenogenetic and that the spermatozoön plays only the first part of its normal rôle, that of initiating development. The formation of the embryo is stated to be purely a matter of the egg and therefore inheritance is strictly maternal. In one case Loeb cites evidence of a paternal influence in heredity but seems to have some hesitancy about presenting the data. The claim is made that the heterogenic cross in which he noted this paternal inheritance is difficult to get but I have had no difficulty in making this cross almost any day during the months of June and July. In the other three heterogenic crosses Loeb was considerably more successful in getting advanced stages than Moenkhaus had been, but he was unable to note any paternal influence exoept that all the embryos were more or less retarded in development and abnormal in structure, resembling pure bred embryos reared in weak $\mathrm{NaCN}$ in sea water. The final conclusion is that these 'parthenogenetic' embryos are pathological because of differences in the nature and rate of the chemical reactions involved. This seems to imply that the sperm does something more than initiate devèlopment, but it will be better to defer discussion of this point until the extensive data forming the body of this paper have been presented.

Quite recently Günther and Paula Hertwig have entered the field of Teleost hybridization. In addition to a number of homogenic crosses they have made a number of heterogenic crosses, all between families of the same order and none between different orders:

Gobius jozo 우

Gobius capito \&

\}$\times$ Crenilabrus pavo $\sigma^{7}$

in both of which only pathological undifferentiated embryos were formed;

Crenilabrus pavo $\circ \times\left\{\begin{array}{l}\text { Gobius jozo } \sigma^{7} \\ \text { Gobius capito } 0^{7}\end{array}\right.$

in both of which development stopped before gastrulation; Crenilabrus pavo $q \times$ Box boops $n^{x}$, in which there appeared many advanced embryos, with large well formed eyes, short tails and 
considerable body pigment (these were not followed through but were preserved after two days); Crenilabrus pavo o $\times$ Smaris alcedo $\sigma^{7}$, in which most of the embryos died during gastrulation but a few developed optic vesicles and went no farther.

In connection with each of their experiments the Hertwigs studied the behavior of the chromatin in cleavage and found no chromatin elimination such as is described by Baltzer for heterogenic Echinoderm hybrids. This result agrees with Moenkhaus' earlier work on similar material, and that of Morris ('14), who studied the behavior of chromatin in Fundulus heteroclitus eggs fertilized with the sperm of Tautogolabrus adspersus. Miss Morris had no success in rearing hybrid embryos of this or the reciprocal cross.

These papers are all that I have found that deal with heterogenic Teleost crosses. Some of my own papers and those of Kammerer, List, etc., dealing with homogenic crosses need not receive attention here.

The following distinct problems seem to arise out of this survey of the literature: (1) Is success in development of hybrids correlated with the nearness of relationship of the species crossed? (2) What factors underly the differences in success in development and in heredity between reciprocal crosses? (3) Is the development of heterogenetic crosses parthenogenetic and therefore purely maternal? (4) What is the relationship existing between the degree of normal functioning of chromatin during cleavage and the development and heredity of hybrid embryos? It is hoped that the large mass of data hereinafter presented will to a large extent clear up some of these problems.

\section{MATERIALS AND METHODS}

Table 1 shows the systematic relationship of the fourteen species used. The classification of Jordan and Evermann ('00) is adopted throughout the present paper. I was unable to obtain ripe eggs of three of these species: Poronotus triacanthus, Menedia beryllina cerea, and Morone americana. Males 
TABLE 1

Giving a list of the species of fish crossed

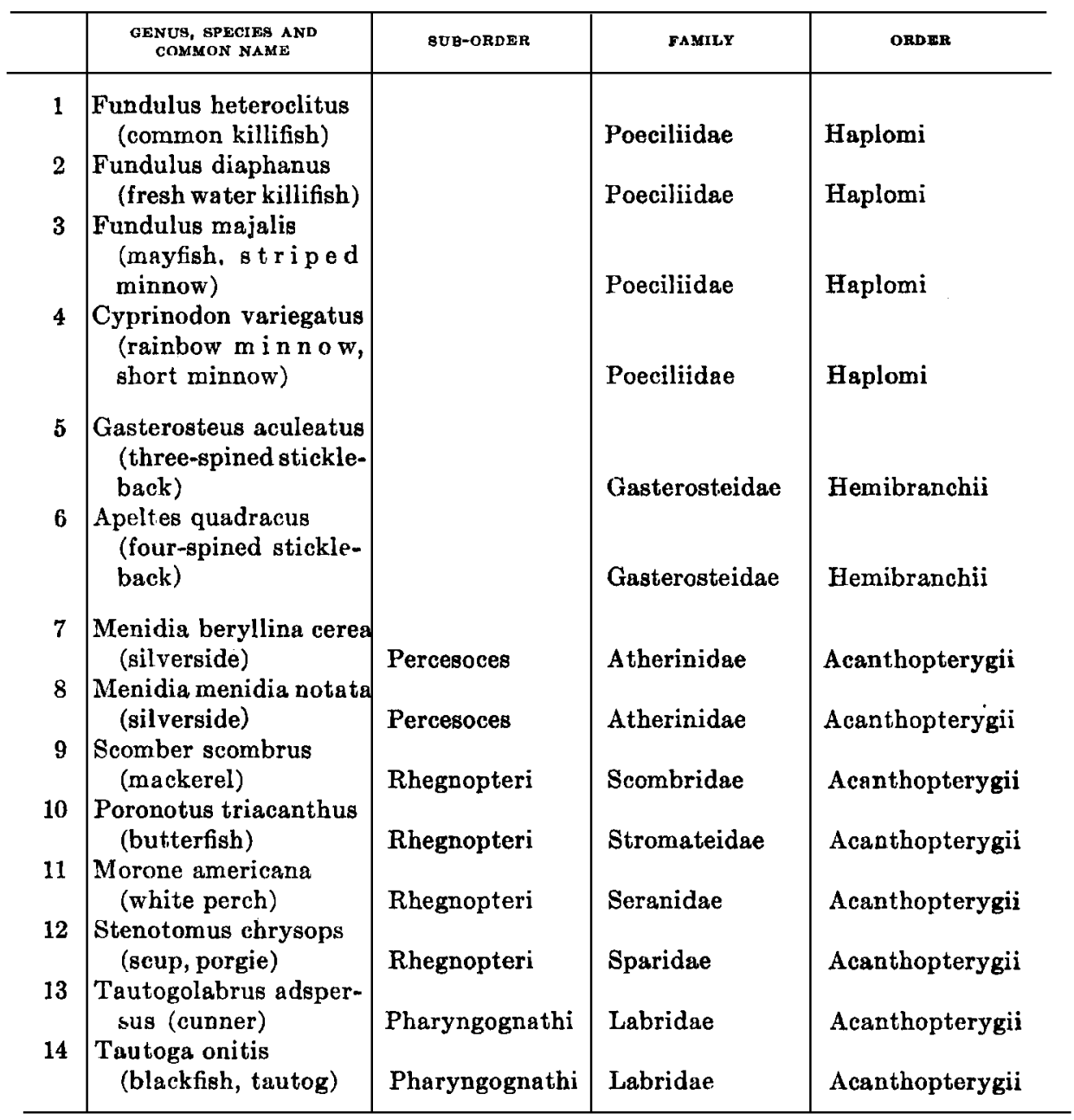

of the first two species were abundant for a long time, but no ripe females were brought in. Only one specimen of Morone was secured, a ripe male that lived for some time in the aquarium and furnished excellent material for a number of crosses.

The usual methods of preventing accidental fertilization of eggs by sperm of the same species were carefully followed, 
hands and instruments being washed in fresh water before each new experiment. As a farther precaution against accidental fertilization, we avoided the use of any males of a given species when experimenting with the eggs of that species. In only a few cases therefore were controls of pure bred eggs started at the same time as the hybrids. In the case of Gasterosteus and Apeltes females were abundant and males rare. In the former species males were not found until late in the season after all the crosses with the eggs of that species had been made. Hence there was no chance of accidental fertilization in this species. In the case of Apeltes, only an occasional small male was secured and, since no milt could be squeezed out under pressure, it was necessary to dissect out and macerate the testis in order to get any sperm. This was also true of Cyprinodon and only to a slightly less extent of the three species of Fundulus. Hence chance fertilization is out of the question in crosses involving the females of these species. In general I would add that even without any special precaution against it, accidental fertilization is highly improbable. During eight years of work with fish eggs I have never had a single embryo develop in an experiment with eggs that had not been intentionally fertilized. It should therefore be understood at the beginning that the results here reported are not to be discredited as due to accidental homogenic fertilization. We can vouch for the kind of sperm responsible for development in each cross.

The plan for presenting the data is as follows. All the crosses made upon a given species of egg are grouped together under a general heading and the various crosses are taken up in the order in which the species are listed in table 1. General remarks about the breeding habits, the peculiarities of the eggs, their rate of development and the special heritable characters of the pure-bred larvae, are made in introducing experiments with each species of egg. It seems advisable to employ in the descriptions of the different crosses the utmost abbreviation consistent with clearness of statement. It is hoped that the reader will pardon a certain amount of unavoidable abruptness in diction. When a date is mentioned it refers to one experiment 
started on that day. Two or more dates mean two or more different experiments. Occasionally, two or more experiments of the same kind were made on one day and this is indicated in parenthesis after the date.

\section{CROSSES WITH THE EGGS OF FUNDULUS HETEROCLITUS}

This species has furnished material for a large amount of experimental and developmental work. The average diameter of the egg is about $2 \mathrm{~mm}$. When first laid the eggs are covered by a sticky fibrous coat which causes them to adhere to any bodies with which they come in contact and, under laboratory conditions, to form clumps of various sizes. In order to insure normal development of either pure or hybrid embryos of this species it is necessary to dissect apart these egg clumps as soon as possible after fertilization. These eggs are remarkable for their hardiness and ability to resist untoward conditions. This hardiness is probably responsible to a considerable extent for the success with which this species hybridizes with many other forms. The development is comparatively slow, requiring twelve to fifteen days to reach the stage of hatehing. Young larvae live well in finger bowls or snall balanced aquaria. Detailed studies of the embryonic and larval chromatophores of this species and of their inheritance have been made by Bancroft ('12) and Newman ('08 and '14). Both red and black chromatophores occur on both body and yolk. The black cells are characteristically polygonal in shape and have only a few short branches. In addition they exhibit a tendency to fuse in dense groups. The red cells are intricately branched but do not fuse. In abnormal specimens both types of chromatophores may show a modification of the typical form, the blacks tending to branch and the reds to be a more solid-bodied and less branched. These characteristics of the chromatophores are strongly inherited in homogenic crosses as shown by the authors mentioned above.

$F$. heteroclitus $\& \times$ Gasterosteus aculeatus $\sigma^{T}$. No males of Gasterosteus were found until July 4th. Two experiments 
were performed July 4 and 9. The failure to secure males of the paternal species earlier in the season may be due to the fact that during the height of the breeding season of the stickleback, males stay about the nest to guard the eggs, and hence they escape the seine. In both experiments a large per cent of the eggs cleaved and developed normally up to the closure of the blastopore. Slender embryos with optic vesicles and a few somites were formed. These shortly disintegrated without developing farther. The chromatophores did not reach a definitive condition and therefore it was impossible to decide whether or not the maternal type was modified. It is my belief that this cross would have been more successful earlier in the season as both species had passed the height of their spawning activities before the experiments were made.

$F$. heteroclitus $\& \times$ Apeltes quadracuis $\sigma^{7}:$ June 17 and 25 . In the first experiment a large proportion of eggs developed normally up to an early periblast stage. Many then disintegrated but a few formed short shapeless embryos with little or no head differentiation. In none did the germ-ring go more than half way around the yolk. The second experiment was more successful. Only about 10 per cent cleaved but nearly all of these continued to develop through the germ-ring stages until the closure of the blastopore. Five embryos were developed in which the body was long and slender but no head differentiation was evident. Much pigment totally foreign to that characteristic of F. heteroclitus was formed on body and yolk. All chromatophores were slender and intricately branched. No red chromatophores appeared. This is the only case in which I have observed in heteroclitus egg hybrids the total suppression of the red chromatophore so characteristic of that species. I do not care, however, unduly to emphasize this observation as I was unable to repeat the cross.

$F$. heteroclitus o $\times$ Menedia beryllina cerea $\sigma^{7}$ : June 19 and 29 . The first experiment showed a large proportion of eggs cleaving normally. These safely passed through the germ-ring stages and many of them formed normal embryos with well developed eyes, otic vesicles, long tails, string heart; but in none was the 
circulation established. Pigmentation on the body was of a modified F. heteroclitus type; that on the yolk seemed to be pure maternal but did not reach the definitive stage. The second experiment was similar to the first except that three individuals developed circulation in both body and yolk. These grew well for some days but gradually the heart slowed down and stopped. It may be that these embryos became infected and therefore met an unnatural fate as it is unusual for embryos that have established a circulation to fail to hatch. The embryos that reached the most advanced stage of development were strikingly like the maternal species while many of the less successful embryos showed decided traces of the paternal influence in their chromatophores. Moenkhaus described this cross using the name Menedia gracilis. His results are in accord with mine except that he never noted any embryos with circulation.

$F$. heteroclitus $q \times$ Menedia menedia notata $\sigma^{7}$ : June 19 and 29. In the first experiment over 90 per cent of eggs cleaved and at least 50 per cent developed normally through gastrulation. The majority formed eyes with lenses, otic vesicles, a long tail, pulsating heart, etc. On the sixth day five specimens had established perfect circulation. One hatched on the fifteenth day, one on the sixteenth, and two on the seventeenth. These larvae lived for twelve weeks in a small balanced aquarium and were still alive when this account was written. I have been unable to note any differences between these hybrid larvae and those of purebred F. heteroclitus. The less successful embryos lived for a long time and although they did not develop a circulation continued to differentiate many organs. They show a mosaic of paternal and maternal chromatophores on both body and yolk. The heart lies in an enlarged pericardium situated in front of the head. As this pericardium grows the heart elongates and extends across from its point of attachment on the embryo to that on the opposite side of the pericardium. Though these hearts are under tension during their entire development they differentiate as though they were in normal position. The four chambers, the valves and the flexures appear in almost normal form, and the heart beats with normal rhythm although 
it contains no blood. In some cases the heart becomes detached from the embryo and lies on the opposite side of the yolk; yet it still pulsates normally (fig. 1). In other cases the distal end of the heart breaks loose, leaving the free end wagging backward and forward like a dog's tail. These abnormal hearts furnish excellent examples of automatic differentiation of embryonic tissues. One is impressed with the conviction that certain tissues are predestined to form organs no matter what their

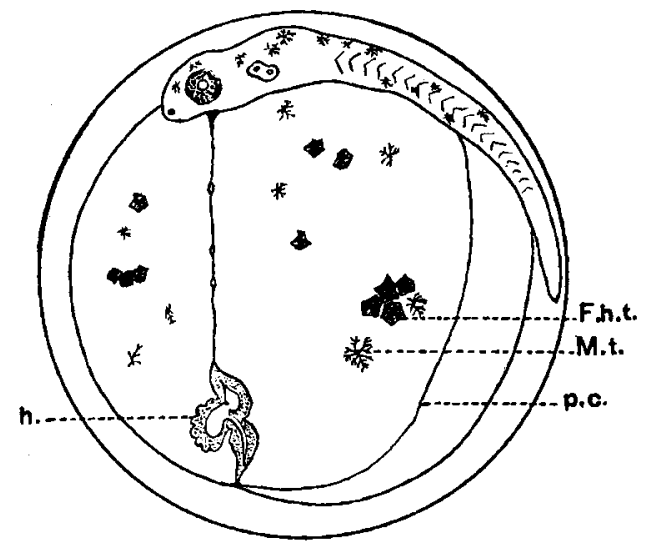

Fig. 1 A common type of hybrid embryo from Fundulus heteroclitus $q \times$ Menidia menidia notata $\sigma^{7}$ (fifteen days old). Note the heart $(h)$ which, though connected with the embryo by only a delicate thread, beats with an almost normal rhythm. The heart is stretched across the abnormally large pericardium the margin of which $(p . c$.$) is seen to the right. In embryos of this type both parental$ specific types of black chromatophore are present, the squarish $F$. heteroclitus type (F.h.t.) and the finely branched Menidia type (M.t.). Embryos showing this degree of paternal influence seldom develop further than this specimen.

developmental relations may be. Certainly correlative development seems unnecessary in the case of these hearts for they develop their flexures and chambers when stretched instead of being crowded as in normal development. Again when we find isolated hearts beating normally without any blood we are impressed with the extreme independence of the heart mechanism. It would be of interest to determine whether such embryonic hearts have ganglion cells. The second experiment was less successful though many well developed embryos appeared. 
These displayed active muscular movements, normal heads and beating hearts; but in none was normal circulation established and in all was the paternal influence evident in the chromatophores. This cross was studied extensively by Moenkhaus who describes in detail the characters of the unsuccessful hybrid embryos. Only one specimen was seen by him to have established a circulation and even this did not hatch. This result is rather in contrast to mine in which five individuals hatched and lived for weeks. It is probable that the unusual combination of cool weather and care in segregating the best embryos accounts for my larger measure of success. Loeb ('12) evidently had little trouble in getting advanced embryos from this cross for he described cases in which a circulation had been established, but none hatched.

F. heteroclitus $\$ \times$ Scomber scombrus or: June 18, 27, and 30 . In many respects this was the most remarkable cross made on account of the striking opposition between the two species used and the marked success in development of the hybrids. All three experiments gave practically identical results, for in each some individuals developed a circulation. In the first experiment one embryo hatched and lived as an active larva for nearly three weeks. All of those that established a circulation were almost pure maternal in character, showing little or no evidence of mackeral parentage. Many of the other hybrids went on developing for at least two weeks and formed fairly normal larvae with pectoral fins that moved rhythmically. They seemed to be ready for hatching but were unable to escape from the egg membrane. A large number of the embryos that failed to establish a circulation developed a high degree of head differentiation and their chromatophores continued to grow until they reached the definitive condition. In many of these retarded embryos the chromatophores were prevailingly maternal, but side by side occurred the squarish black chromatophores of $F$. heteroclitus and the intricately branched ones of the mackerel. Sometimes from a solid squarish body there ran out a slender branching offshoot. Red chromatophores appeared in nearly all embryos and, though slightly less in- 
tricately branched, were evidently pure maternal. The most remarkable of all the chromatophore characters was discovered by Mr. Larrabee and confirmed by me. In a considerable number of embryos there occurred the strikingly specific green pigment cells of the mackerel. These green cells are perhaps the most highly specific of the pigment characters found in the mackerel and they never occur in pure F. heteroclitus, hence it would be difficult to find a clearer case of paternal inheritance in a heterogenic cross. This cross affords a graded series of individuals showing all stages of success in development from those that died during gastrulation to those that hatched and lived for weeks as normal larvae. Some of the retarded embryos show all stages of heart development seen in other crosses. Others show the pectoral fin developing out on the yolk at a distance from the embryo and in still others an extensive pericardium appeared without any heart. As F. heteroclitus eggs hatch in from twelve to fourteen days and those of Scomber hatch in less than three days we are dealing with the engrafting of two very different ontogenies and it is surprising that development is as harmonious as it is. In no case was there any hastening of the slower F. heteroclitus egg by the sperm of the more rapidly developing mackerel. On the contrary the development shows an early retardation and even the most successful individuals are belated in their hatching. Evedently then the rate of development is not eapable of being inherited through the sperm. This cross furnishes a remarkably clear demonstration of the fact that in heterogenic crosses the maternal and paternal heredity factors are simultaneously operative. In some individuals the maternal factors seem to predominate almost to the exclusion of the paternal. In others the paternal and maternal factors seem to be about evenly balanced and in still others (very rare) the paternal factors are dominant. One specimen in particular was noted in which the yolk was covered with a delicately branched network of chromatophores of the mackerel type, none of the solid-bodied polygonal chromatophores of the maternal species being present. Not a single red chromatophore so characteristic of F. hetero- 
clitus was present. In general it may be said that the most successful embryos are most nearly pure maternal and that those which exhibit well defined traces of paternal influence are markedly less successful.

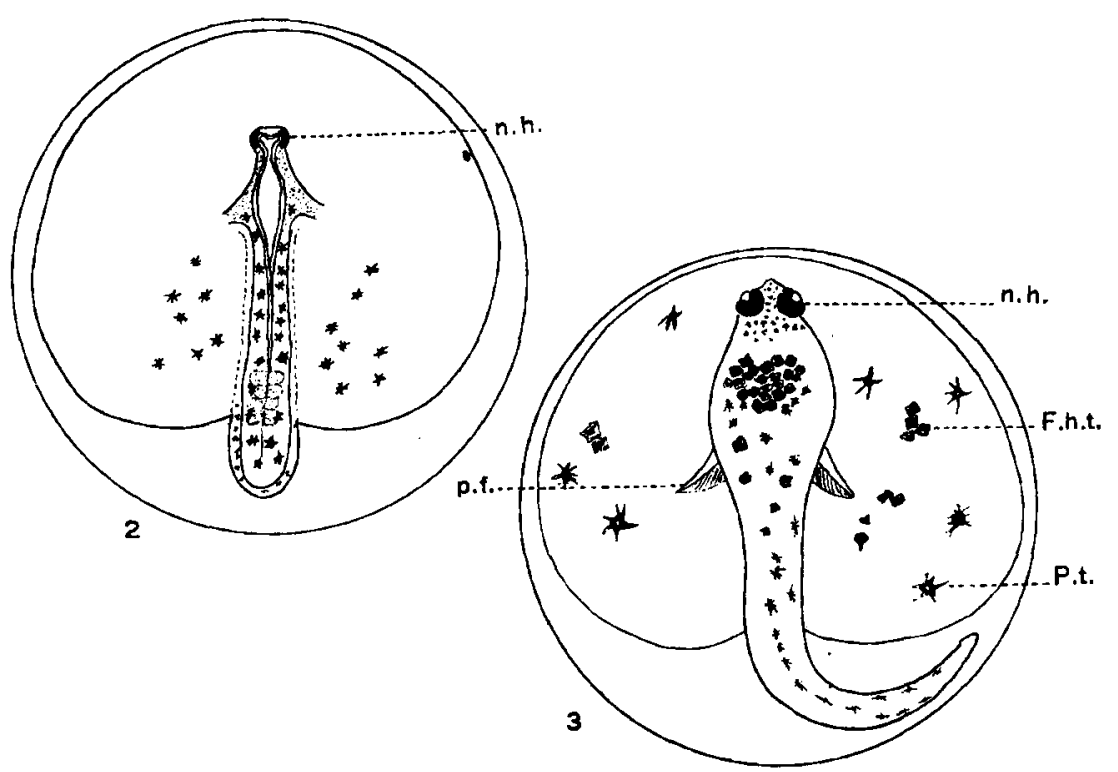

Fig. 2 Hybrid embryo from Fundulus heteroclitus $q \times$ Poronotus triacanthus $\sigma^{7}$ four days old. Note the narrow head $(n . h$.$) with rudimentary eyes and$ the stellate chromatophores. This is the maximum stage of development reached by embryos of this cross in most of the experiments.

Fig. 3 Exceptionally advanced hybrid embryo from Fundulus heteroclitus $\& \times$ Poronotus triacanthus $\sigma^{7}$. The head is still a 'narrow head' ( $\left.n . h.\right)$ although much more advanced than usual. Note the two types of black chromatophores, the squarish F. heteroclitus type (F.h.t.) and the stellate Poronotus type (P.t.). Pectoral fins $(p . f$.) are well developed; a considerable amount of yolk has been consumed, although no circulation has been established. This embryo was fifteen days old when drawn.

F. heteroclitus $+9 \times$ Poronotus triacanthus $\sigma^{7}:$ June 17, 19, 25, 26, and July 6 and 11. The results of all the experiments were strikingly similar. Nearly all the eggs cleaved normally and development though slower than the control appeared perfectly normal until the third or fourth day, when a highly characteristic type of embryo was formed, which we have called 
'narrow-heads' (fig. 2). Only rarely did well defined optic vesicles appear and only in one case did eyes with lenses develop (fig. 3), and these were very small though normal in appearance. The great majority of the 'narrow-heads' showed no brain differentiation anterior to the otic vesicles. From there back however they appeared to be quite normal, forming pulsating hearts, many somites and a tail. After five or six days, however, development ceased and dedifferentiation set in, resulting in the formation of lumpy embryonic masses still retaining a spark of life. The most successful embryo appeared in the experiment of June 17 (fig. 3). It was normal in appearance until the end of the sixth day. After that time the head anterior to the otic vesicles ceased to develop and possibly diminished in size. Pectoral fins appeared and the embryo lived till July 8 when it began slowly to dedifferentiate and eventually died, without establishing a circulation. Not having been able to secure the eggs of the butter-fish I am unable to say anything definite about the paternal inheritance. It seems strange that the F. heteroclitus eggs should cross so much less successfully with the butter-fish than with the mackerel for both of the paternal species are equally distantly related to the maternal.

$F$. heteroclitus \& $\times$ Morone americana $\sigma^{7}$ : June 25. Only one ripe male of Morone was obtained. Early cleavage was rather irregular but development proceeded to the end of the cleavage period. No embryos formed a germ-ring, hence development ceased at the beginning of gastrulation.

F. heteroclitus o $\times$ Stenotomus chrysops $\sigma^{7}:$ June 17, 19, 26, 30, and July $\%$. Scup males with abundant milt were always at hand and every opportunity for normal development was given the eggs. In four experiments no embryos reached the stage of blastopore closure and none showed any head differentiation. In one experiment, however, a considerable number of embryos succeeded in closing the blastopore and developing long slender headless bodies which were covered with small delicately branched chromatophores totally unlike those of $\mathrm{F}$. heteroclitus but exactly like those of the scup. These embryos seemed to retain their vitality for many days after this period but did not develop farther. 
F. heteroclitus $\circ \times$ Tautogolabrus adspersus $\sigma^{7}:$ June 13, $19,24,29$. There was a wide difference in the success of development observed in the various experiments. In those of June 13 and 2980 per cent to 90 per cent cleaved and developed normally up to various germ-ring stages but none succeeded in closing the blastopore. Of these fertilized on June 24 the majority succumbed during the germ-ring stages but five closed the blastopore and produced embryos with eyes, lenses, otocysts, pulsating hearts but without circulation. On the sixth day all were dead. In the experiment of June 19 about 20 per cent of the eggs cleaved. These developed normally through the early germ-ring stages but only two succeeded in closing the blastopore. One of these failed to establish a circulation but the other continued to develop and hatched on the eighteenth day. This larva appeared to be normal and healthy but died in about a week. The other specimen that had established a circulation but failed to hatch lived considerably longer but gradually died of anemia. Moenkhaus made this cross five times but in no case did embryos develop beyond middle germring stages. This result agrees with my experiments of June 13 and 29 but differs materially from those of June 19 and 24 . Morris ('14) made this cross many times but did not attempt to rear the hybrids. Loeb, however, got a number of advanced hybrid embryos with "eyes, ears, fins, pigment and heart beat;" and some developed a circulation which lasted for three or four days, but none were observed to hatch.

$F$. heteroclitus $\$ \times$ Tautoga onitis $\sigma^{\top}:$ June 18 and July 3 . In both experiments a large per cent of eggs proceeded normally through cleavage stages and a few reached late germ-ring conditions but failed to close the blastopore (fig. 4). Faint pigmentation appeared but it was not possible to identify the parental types of chromatophores. Moenkhaus made this cross three times with results similar to those just described. 


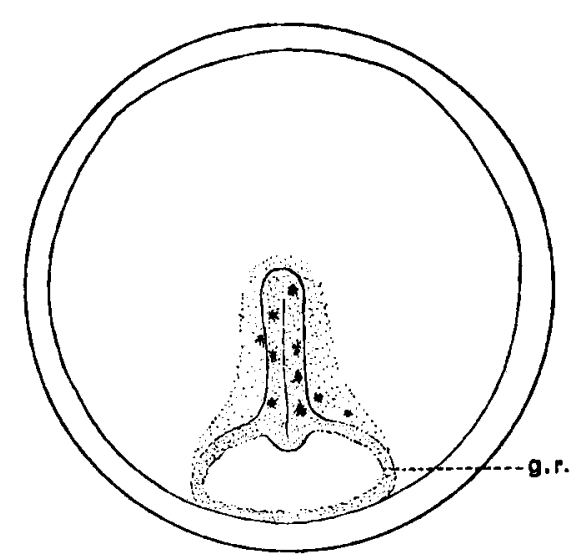

Fig. 4 Young hybrid embryo from Fundulus heteroclitus $q \times$ Tautoga onitis or (four days old). This represents the maximum stage of development attained in this cross. The germ-ring ( $g . r$.$) never completely surrounds the$ yolk, and very little embryonic differentiation occurs. Note, however, that chromatophores develop independently of other tissues.

\section{CROSSES WITH THE EGGS OF FUNDULUS DIAPHANUS}

F. diaphanus is a fresh and brackish water species closely related to $\mathrm{F}$. heteroclitus. The egg is a little larger than that of the latter and is more transparent. The eggs are laid by the females when clasped by the males, as in $\mathrm{F}$. heteroclitus, and adhere by means of the sticky fibrous covering to aquatic vegetation. Very few eggs of this species were available this year but in previous seasons I have crossed $F$. diaphanus with $F$. heteroclitus, F. majalis, and Cyprinodon, all of the family Poeciliidae, and with Tautogolabrus adspersus. In general the results are similar to those for $\mathrm{F}$. heteroclitus, except that the egg does not seem to be so tolerant of the sperm of distantly related species. Hybrids from F. diaphanus eggs and the sperm of Poronotus, Stenotomus, and Tautogolabrus, go no farther than the germ-ring stages. The fact that $\mathrm{F}$. diaphanus is practically a fresh water species introduces an element into the crosses that may be responsible for the lack of success in the development of heterogenic hybrids made on this species of egg. More work is needed on these crosses before any definite conclusions can be drawn. 


\section{CROSSES WITH THE EGGS OF FUNDULUS MAJALIS}

The eggs of F. majalis are the largest and most heavily yolkladen of any used in these experiments. They average $3 \mathrm{~mm}$. in diameter and are of an opaque yellow color. The egg envelope is sticky but not fibrous as in other species of Fundulus. Presumably the eggs are laid under the stimulus of the clasping male, as I have observed upon two occasions males clasping females. I have as yet failed to find any species of Teleost which can be crossed with any marked degree of success upon F. majalis eggs. Even members of the same genus fail to produce any hatched larvae (Newman '08, '14).

$F$. majalis $\$ \times$ Apeltes quadracus $\sigma^{7}:$ June 30 . Only three eggs cleaved but these were isolated and well cared for. They succumbed however during late germ ring stages after forming only a broad, flat embryo without any visible differentiation.

F. majalis of $\times$ Menidia beryllina $\sigma^{7}$ : June 30 . Only ten eggs cleaved, developing short embryos with brain lobes but no optic vesicles. A short upturned tail developed although the blastopore never completely closed (fig. 5.) Chromatophores appeared but never reached a definitive stage.

$F$. majalis $\& \times$ Menidia menidia notala $\sigma^{\circ}:$ June 30 and July 1. Nearly all the eggs cleaved and developed normally up to early periblast stages, when the great majority died. Seven embryos continued to develop and were isolated and well cared for. These grew well and developed pigmented eyes, otic vesicles, many somites, pulsating string heart; but no circulation was established. The chromatophores of the two species involved are so similar that it was not possible to determine the paternal influence.

F. majalis $\& \times$ Poronotus triacanthus $\sigma^{\top}:$ June 30 and July 14. In both experiments the majority of cleaving eggs developed advanced embryos with well differentiated head parts, the eyes being large and heavily pigmented (fig. 6). The blastopore never successfully closed; a short movable tail developed; the chromatophores showed no trace of the paternal influence; no heart beat was visible and no pericardium appeared. These curious embryos appeared to be specific for this cross. 


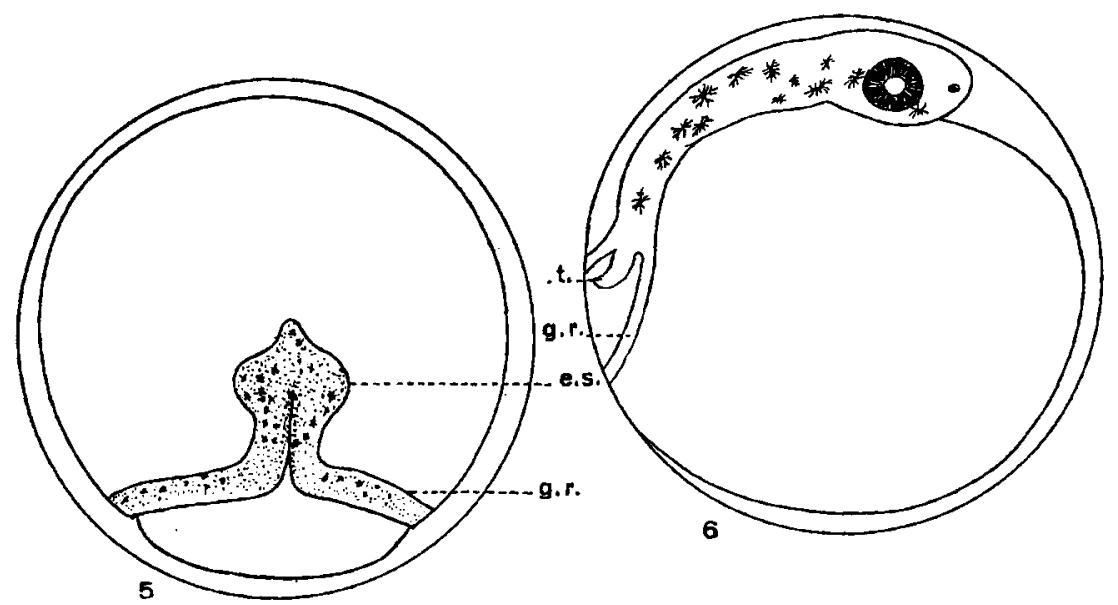

Fig. 5 Type of retarded embryo from Fundulus majalis $q \times$ Menidia beryllina cerea $\sigma^{7}$ (at maximum stage of development, five days). The embryonic shield (e.s.) is short and stands high above the yolk and the germ-ring (g.r.) is thick and well defined. Black pigment granules have begun to appear.

Fig. 6 Typical embryo from Fundulus majalis $\& \times$ Poronotus triacanthus $\sigma^{x}$, showing persistent germ-ring (g.r.) and rudimentary tail $(t$.$) . This stage$ is a week old and at its maximum phase of development.

\section{CROSSES WITH THE EGGS OF CYPRINODON VARIEGATUS}

Cyprinodon is a small brackish water fish commonly called the 'short minnow' or 'rainbow minnow.' The spawning habits (described by Newman, '07) are very similar to those of F. heteroclitus and other members of that genus. The eggs are smaller than those of any of the Fundulus species, being on the average less than $1.5 \mathrm{~mm}$. in diameter. They are covered with a fibrous sticky coat similar to that of $F$. heteroclitus. The yolk is almost colorless and the egg, except for its envelope, is almost as transparent as a pelagic egg. Embryos hatch in seven or eight days and the larvae live well in finger bowls. It is somewhat difficult to obtain females with ripe eggs but every season for some years past $I$ have secured a few such individuals. In previous seasons I have crossed the eggs of Cyprinodon with all three species of Fundulus and with the cunner (Newman '14). 
Cyprinodon variegatus $\$ \times$ Apeltes quadracus $\sigma^{7}:$ June 29. Nearly all of the eggs cleaved normally but went no farther than early periblast stages.

Cyprinodon variegatus $\&$ Menidia menidia notata ${ }^{\top}:$ June 29. About 40 per cent of the eggs cleaved normally. After twenty hours these had reached early germ-ring stages. Three embryos proceeded to late germ-ring stages and then broke down without closing the blastopore or developing a distinct embryonic axis.

Cyprinodon variegatus o $\times$ Scomber scombrus $0^{7}:$ July 1. Only about 10 per cent of the eggs cleaved. These developed to the end of the cleavage period but died without forming a periblast.

Cyprinodon variegatus $\& \times$ Stenotomus chrysops $\sigma^{\top}:$ July 1 and 3 . Nearly all eggs in both experiments cleaved and were in normal periblast stages after nineteen and twenty hours. After forty-four to forty-six hours all embryos were found to be disintegrating in early and middle germ-ring stages, without forming distinct embryonic axes.

Cyprinodon variegatus $\odot \times$ Tautogolabrus adspersus $\sigma^{7}:$ June 25, 1919, and July 1, 1914. In the first experiment all embryos ceased to develop in advanced cleavage stages but in the second a large number of embryos developed normally up to late germ-ring stages showing the neural groove partly closed, primary brain vesicles, but no farther head differentiation. A little later disintegration set in and all the embryos died.

Cyprinodon variegatus of $\times$ Tautoga onitis $\sigma^{3}:$ July 3 . 'About half the eggs cleaved and developed normally for about eighteen hours, at which time the periblast was seen to be growing normally over the yolk but the central cells of the blastodisc showed unmistakable signs of cytolysis; none formed a distinct germ-ring.

It may be said by way of summary that Cyprinodon eggs appear to be ill adapted for hybridization. In all of the nine crosses the developmental block occurs early or late in the gastrulation process and no distinct embryonic differentiation occurs. The most advanced condition is reached by the interorder cross Cyprinodon $q \times$ Tautogolabrus $\sigma^{\top}$ where the first 
steps in embryonic differentiation are taken. It should be especially noted that after repeated trials Cyprinodon refuses to develop beyond the gastrulation stages when crossed with any of the species of Fundulus, a genus belonging to the same family as Cyprinodon (Newman '14). The cause of this failure on the part of Cyprinodon to hybridize successfully is probably associated in some way with the constitution of the egg cytoplasm. Some specific material of the egg is doubtless so highly individual and so delicately balanced that no foreign germ plasm can successfully coöperate with it in the building up of embryonic characters. Any species of sperm seems to be able to take part in cleavage and to start gastrulation but only sperm of the same species can coöperate in embryonic differentiation.

\section{CROSSES WITH THE EGGS OF GASTEROSTEUS ACULEATUS}

The breeding habits of the sticklebacks are well known. The male makes a nest of grasses in which the eggs are laid and fertilized; he then guards the nest. During the best part of the spawning season no males were secured although large numbers of ripe females could be obtained at any time. Early in July, however, when the spawning season was on the wane a number of males were obtained and were easily distinguished from the females by the salmon pink coloration of the jaws, operculum, and pectoral fins. The eggs are stripped only with some difficulty. On considerable pressure they burst forth from the genital opening along with a quantity of thick mucilaginous jelly which serves to cement them into a mass or a single layer on the bottom of the vessel. After some hours the mucilaginous material becomes thinned by the sea water and may be drawn off with a pipette as a thick syrupy fluid. The eggs, however, remain rather firmly massed but may be separated by the use of some force. Many of the normally developing eggs retain the shape impressed upon them by contact with their neighbors, but this change in shape does not affect the form of the pure bred embryos. 
The eggs have a rather thin envelope and measure on the average a little less than $1.5 \mathrm{~mm}$. in diameter. They are of a clear yellowish tint, the yolk appearing to be of about the same density as that of $F$. heteroclitus. Pure-bred embryos hatch in about six or seven days and the larvae live well in aquaria.

Gasterosteus aculeatus $\% \times$ Fundulus heteroclitus $\sigma^{7}:$ June 15, 18 (at 10:15 a.m. and again at 4 p.m.). The three experiments gave three different results. In the first the middle cleavage stages of many showed a loose cell texture, with peripheral cells deeply separated and giving a serrated profile much like those figured by the Hertwigs, for the cross Crenilabrus pavo $\$ \times$ Smaris alcedo or. (Hertwigs '14, fig. 13). In others the cleavage was normal and development proceeded in typical fashion, though more slowly than in the control, up to middle germ-ring stages. At this time the margin of the germ-ring ceases to advance and begins to retreat toward the animal pole of the egg where out of an accumulation of embryonic cells a short-bodied embryo develops that exhibits a considerable degree of differentiation. In some of these embryos well formed movable eyes occur together with large otic vesicles and brain lobes. Pigmentation was not carried very far in this experiment and the specific characters of the parent species could not be determined. In none of the embryos did a heart or pericardium develop. In the second experiment fewer embryos appeared and these disintegrated in late germ-ring stages after forming a distinct embryonic axis. The third experiment, however, was more successful than either of the others. About 6 per cent of the eggs cleaved normally and did not produce any of the crenated blastoderms described for the first experiment. More than half of the embryos developed in a normal way through the period of gastrulation and gave rise to well formed individuals with optic vesicles a little vague but with well defined otic vesicles and many clean-cut somites. Many went no farther than this but all continued to differentiate chiefly at the head end, forming darkly pigmented eyes and large swollen otic vesicles. The chief abnormality appeared at the posterior end, for the 
tail was blunt and short and much too small for the body. The chromatophores appeared as a mosaic of the two parental types. One who has made a careful study of these cells in F. heteroclitus could not fail to recognize the foreign character of some of the chromatophores forming this mosaic. Curiously enough none of the embryos developed a heart or pericardium and hence all died of inanition after about twelve days. This cross furnishes a good example of the fact that the results of crossing two different species are not always the same. Had I stopped after two experiments I would have concluded that this cross does not go through the gastrulation period. Such considerations should make us pause in stating that any cross has certain definite limitations. I have little doubt but that some of the experiments that have gone badly with me will be successfully carried through to hatching by some other worker.

Gasterosteus aculeatus $\% \times$ Fundulus diaphanus or: July 14. This experment was made too late in the season for the best results. Only about 20 per cent of the eggs cleaved. After twenty-four hours these were in early germ-ring stages which showed signs of disintegration. None lived through the gastrulation period.

Gasterosteus aculeatus $\& \times$ Fundulus majalis $\sigma^{7}:$ June 25. About 80 per cent of eggs cleaved and developed normally through the cleavage period. Many of these lived through the middle germ-ring stages, formed well defined embryonic axes, but none succeeded in closing the blastopore or in developing any distinct embryonic organs.

Gasterosteus aculeatus $\& \times$ Cyprinodon variegatus $\sigma^{7}:$ July 8 and 14. The earlier experiment was the most successful although only three eggs out of thirty-eight cleaved. These eggs developed normally through gastrulation and formed a peculiar type of elongated embryo with well formed actively moving tail but strangely twisted head parts. The anterior end of the brain was twisted under or to one side and no eyes were differentiated. Well defined otic vesicles appeared, however, and the embryo was normal from there to the posterior end. No heart or pericardium developed. The chromatophores 
on both body and yolk were much like those of the maternal species. The second experiment gave a much larger per cent of cleaving eggs but no embryos developed beyond the middle germ-ring stages.

Gasterosteus aculeatus $\& \times$ Menidia beryllina cerea $o^{3}:$ June 19 and 24. Both experiments gave essentially the same result except that in the first a much larger per cent (over 90 per cent) of eggs was fertilized. All developed normally through cleavage and the earlier stages of gastrulation. A few failed to complete gastrulation but most of them closed the blastopore and developed into long tailed embryos whose only defect seemed to be a certain vagueness of the head region. No distinct optic vesicles were formed but the body from the otic vesicles backward, including many clean-cut somites and well-developed tail, was normal. No pericardium or heart appeared. The chromatophores continued to differentiate and appeared to be purely maternal, although, without a knowledge of the character of the paternal elements, I am unable to pass judgment on this feature of the inheritance.

Gasterosteus aculeatus o $\times$ Menidia menidia notata $\sigma^{7}:$ July 8 (once at 2 p.m. and again at $2: 40$ p.m.). The results of the two experiments were so nearly identical that only one need be described. Although a very large percentage of eggs cleaved and developed normally through the early germ-ring stages not one succeeded in completing gastrulation. In many, after the germ-ring had nearly surrounded the yolk, there was a retreat of the advancing blastoderm toward the animal pole where a piling up of embryonic cells resulted in the production of a formless embryo. The mass was always more or less clearly bilateral and somewhat larger at the anterior end. There was no indication of brain or other embryonic organs. These masses lived for a long time without undergoing any changes except in connection with their chromatopbores, which continued to differentiate until they reached almost the definitive stages. No trace of paternal influence was noted.

Gasterosteus aculeatus $\circ \times$ Scomber scombus $\sigma^{7}:$ June $2 \%$. About 40 per cent of eggs cleaved, the majority of them normally 
but many irregularly. After seven hours, however, all seemed to be equally normal. About half of the embryos stopped developing at various stages of the gastrulation process. Fourteen specimens completed the closure of the blastopore and developed large well formed eyes, otocysts, and moving tails. Upon the fourth day five were seen to have established a more or less normal circulation, four others had actively pulsating hearts without any blood content, and five were disintegrating after reaching a somewhat less advanced stage. On the sixth day one hatched and lived a normal and active existence for ten days in a small balanced aquarium. Pure-bred embryos of this species will not live much longer than this under similar conditions. The chromatophores on both head and body of the hatched larvae were practically, pure maternal in form but the less successful embryos showed a more or less pronounced influence of the paternal element.

Gasterosteus aculeatus $\circ \times$ Poronotus triacanthus $\sigma^{\circ}:$ June 25 and 26 . In the first experiment about 75 per cent of eggs cleaved and developed normally through cleavage. A few disintegrated at the end of cleavage but the majority went through the gastrulation period successfully and formed 'narrow-heads.' These peculiar embryos closely resemble similar individuals in the cross F. heteroclitus by Poronotus triacanthus. These embryos did not show any differentiation of the head region but were thoroughly normal in the body and tail regions; no pericardium or heart; the chromatophores never reached the definitive stages. The second experiment was like the first except that in it a few advanced embryos appeared with small but well developed heads and with distinct eyes and otocysts. A small pericardium and a feebly beating heart, directly beneath the body, were noted for about a day; no circulation was established in any.

Gasterosteus aculeatus o $\times$ Stenotomus chrysops $\sigma^{\top}:$ June 20 , 24 and July 8. In the first two experiments the percentage of eggs developing was rather small. Those that cleaved almost invariably developed to the middle germ-ring stages but did not succeed in establishing a well defined embryonic axis. The em- 
bryos turned white and the yolk opaque a few hours after development ceased. In the third experiment the results were quite different. About 60 per cent of eggs cleaved and although a large majority of the embryos died in the germ-ring stages or earlier, three succeeded in closing the blastopore and in forming embryos normal in appearance except that the head end seemed to show little differentiation. The chromatophores in all of the embryos were quite unlike those of pure Gasterosteus but resembled the delicately branched cells of the scup.

Gasterosteus aculeatus $\$ \times$ Tautogolabrus adspersus $\sigma^{7}:$ June 24 and 25 . In both. experiments a large percentage of the eggs cleaved and developed normally. About 20 per cent completed gastrulation and continued to develop up to the stage when circulation should be established, but only two embryos succeeded in developing a circulation, the others having empty pulsating hearts. The eyes in the majority of the embryos were large and heavily pigmented. Several cyclopians and two individuals with heteromorphic eyes were found; none hatched, although well cared for; even those that established a circulation died after five days. The delicately branched cunner type of chromotaphore was obvious in all specimens and seemed completely to dominate the maternal type. This is the most pronounced case of the dominance of the paternal characters in heterogenic hybrids.

\section{CROSSES WITH THE EGGS OF APELTES QUADRACUS}

This smaller species of stickleback has presumably the same or similar breeding habits as has Gasterosteus. The great majority of those caught in the seine were females, only a few very small males being obtained. These are readily distinguished from the females on account of their bright red pectoral fins. The testes are minute and have to be dissected out and macerated in order to obtain the sperm. The eggs are a little smaller than those of Gasterosteus, averaging about $1.4 \mathrm{~mm}$. in diameter. They are of a rather deep brownish amber color, the yolk being much darker and less transparent than in Gaster- 
osteus. The process of egg stripping is rather difficult and the eggs burst out in a mass with a quantity of the same sort of gummy substance as that described for Gasterosteus. They may also be separated after some time, as in Gasterosteus. It may be said of the eggs of Apeltes that they hybridize much less successfully than do those of Gasterosteus. In no case did I obtain a hybrid from these eggs in which a circulation was established. I am inclined to attribute this lack of success to the density and indigestibility of the yolk. This topic will be discussed in detail in a subsequent section.

A peltes quadracus o $\times F$. heteroclitus ơ: June 14 and July 5 . In both cases only a small number of eggs cleaved and of these only three in one experiment and five in the other continued to develop beyond the cleavage period. The most advanced embryo showed the blastopore nearly closed and the outlines of small optic vesicles.

Apeltes quadracus $\&$ F $\times$ fundulus diaphanus $\sigma^{7}:$. July 13. Nearly all eggs cleaved and developed normally to the end of the cleavage period and then died.

Apeltes quadracus of $\times$ Fundulus majalis or: July 8. Nearly all of the thirty or more eggs cleaved and all but four proceeded to middle or late gastrulation stages. About twenty, after nearly closing the blastopore, formed short embryos without distinct head differentiation but with well defined though small tail. The pigmentation was not sufficiently advanced at the time of death to determine the facts about inheritance.

Apeltes quadracus $\& \times$ Cyprinodon variegatus $\sigma^{T}:$ July $\%$. The eggs were fertilized dry with macerated testis. A large proportion cleaved normally and seemed to be developing well after eight hours. All were dead and disintegrated the following morning after about twenty-two hours development.

Apeltes quadracus $+\times$ Menidia beryllina cerea $0^{7}:$ July 4 (once at 8:45 a.m. and again 5:20 p.m.). The results of the two experiments were quite similar except that a much larger proportion of the eggs developed in the second than in the first. The most striking characteristic of this cross is that in many cases the head end of the embryo develops independently of the tail end. The 
two sometimes appear on opposite sides of the yolk with a vaguely defined sheet of embryonic tissue between (fig. 8). Sometimes the axis of the tail is nearly at right angles to that of the head. This condition appears to arise through a failure of the germring to remain compressed. It seems to split apart in the midbody region and to undergo a process of dedifferentiation. The heads end abruptly just back of the otocyst and the tail begins

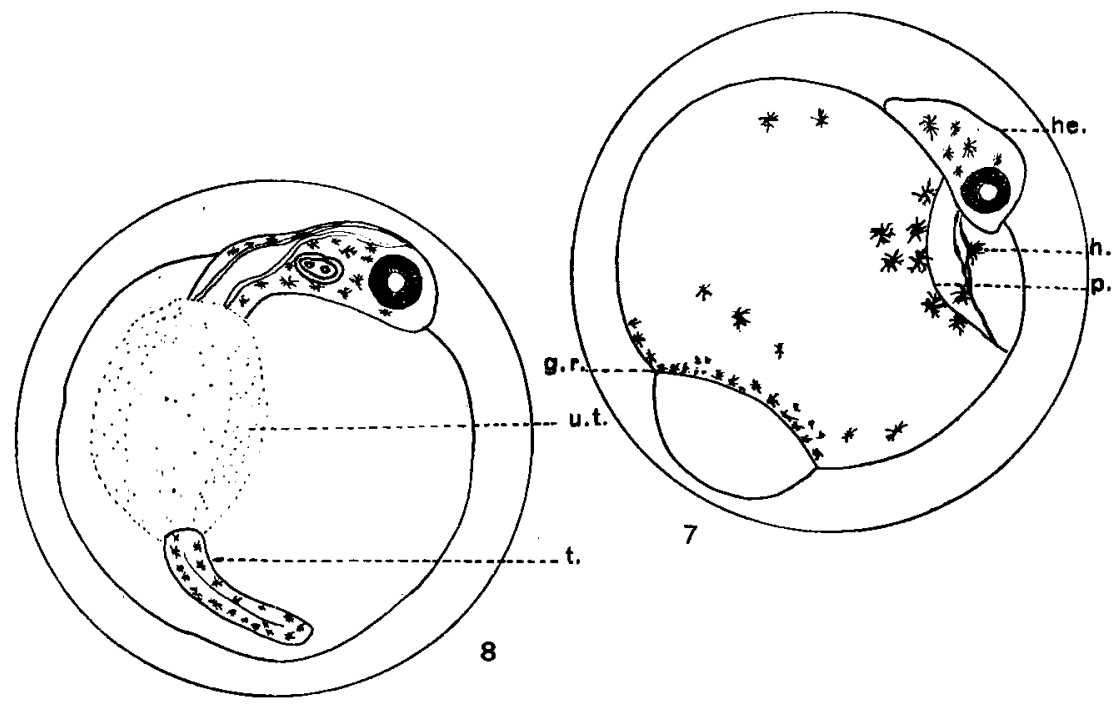

Fig. 7 One of the types of hybrid embryo from Apeltes quadracus $\& \times$ Menidia beryllina cerea $\sigma^{7}$, nine days old. Note that the embryo is practically a trunkless head $(h e)$ with well developed eyes, heart $(h)$ and pericardium $(p)$. The failure to form a trunk and tail is evidently associated with the failure of the germ ring ( $g . r$.$) to close.$

Fig. 8 Another type of hybrid embryo from the same cross as in figure 7, showing head and tail $(t)$ separated by a sheet of incompletely concresced germ ring, composed of undifferentiated tissue (u.t.).

abruptly at some distance from the truncated head. The two parts are often on opposite sides of the yolk and at first I thought I had a peculiar type of polyembryony with one large and one small embryo developing from the single blastoderm. It is clear now however that the two bodies are merely separated parts of a single individual. The head parts are much more 
highly differentiated than the tail parts, having well defined pigmented eyes and branched otic vesicles. Connected with such a head there frequently occurs a pulsating string heart. In some cases a truncated head develops without any tail on the other side of the yolk (fig. 7). Such embryos show clearly the germ-ring incompletely closed. Pigment does not develop sufficiently to show parental characters.

Apeltes quadracus o $\times$ Menidia menidia notata $\sigma^{\top}:$ July 8. About 25 per cent of the eggs cleaved and developed normally to early germ-ring stages. A very few showed the germ-ring one-half to two-thirds around the yolk and a vague embryonic shield, but none completed gastrulation stages.

Apeltes quadracus $+\times$ Scomber scombrus $\sigma^{\top}:$ June 2\%. About 40 per cent of the eggs cleaved but none were developing after twenty-four hours, having disintegrated during or at the end of cleavage. The male mackerel used was rather feeble at the time of the experiment and this may have been responsible for the poor success of the embryos.

Apeltes quadracus $\circ \times$ Poronotus triacanthus $0^{7}:$ June 30. About 25 per cent of the eggs cleaved and developed through the cleavage period. The majority proceeded to gastrulate but none were noted in which the germ-ring was more than halfway around the yolk.

Apeltes quadracus $\& \times$ Stenotomus chrysops ơ: July 7 . Results practically identical with those described for the last cross.

Apeltes quadracus $\& \times$ Tautogolabrus adspersus $\sigma^{7}:$ June 24 and 26 . In the first experiment nearly all eggs cleaved and developed normally to middle germ-ring stages, but none went farther. In the second experiment several embryos almost completed gastrulation but in none was the blastopore completely closed. No well-defined embryonic axis appeared in any case.

A review of the data concerning crosses with the eggs of Apeltes shows that this species furnishes singularly unfavorable material for hybridization, being only a little better in this respect than Cyprinodon. Whether the fault is with the season during which the crosses were made or in the physiological condition of the 
eggs when stripped one can not certainly determine, but I believe that the factors responsible for the ill success in crossing are in no way artificial, but are correlated with some peculiarity of the yolk or other egg materials; for pure bred eggs developed quite normally when handled in the same way as the hybrids.

CROSSES WITH THE EGGS OF MENIDIA MENIDIA NO TATA

For hybridization experiments the eggs of this little silverside minnow are among the most available that I have encountered. The fish, both males and females, are very abundant in the Eel Pond near the laboratory and spawn during the greater part of June and July. The eggs strip readily from the females in bunches of a hundred or more and abundant milt is easily expressed from the males. The adults live well in aquaria and may be kept on hand without showing any deterioration. in either eggs or milt for at least a week. Some of the most successful experiments here recorded have been made with those kept for five or more days. The eggs, averaging less than $1 \mathrm{~mm}$ in diameter, are smaller than any thus far described. In fact, they are the smallest of the shore-laid eggs dealt with in these experiments. In many respects these eggs resemble pelagic eggs, being of about the same size as the latter and resembling them in the possession of a single oil drop, which no doubt acts as a float, so that the eggs are buoyed up from the bottom although attached to weeds by means of long ropy threads. The yolk is transparent and faintly yellow in color. When the eggs are immature they strip as separate units and do not stick together. In the immature stage they are completely covered with threads of a transparent material wound in wavy bands about the chorion. When the eggs are ripe these fibers, which are seldom more than eight to twelve in number, loosen up and separate themselves from the egg surface as long twisted ropes.

All the threads are attached in a bunch to one small area of the egg which appears to be opposite to the micropyle or nearly so. When the eggs are artificially stripped these threads become intricately tangled together so that an almost inextricable 
egg mass is produced. In nature, however, the eggs are apparently extruded one or a few at a time and attached to eel grass, etc., so that they float separately in the water and do not crowd one another. In order to obtain success in development with these eggs it is necessary to approximate natural conditions by dissecting apart the egg masses, a task of considerable difficulty but yielding to a little patience. If the eggs are not separated they show many unhealthy symptoms within twenty-four hours, at which time most pronounced differences in the development of different eggs are seen. Those on the surface may be in advanced gastrulation stages while those in the center show various cleavage stages. In contrast with pelagic eggs which have a rapid development, hatching in two or three days, the eggs of Menidia, both pure and hybrid, require nearly two weeks to hatch. The small active larvae live in the aquaria for only a few days, but hybrids usually live as well as pure bred individuals. It is a general rule among fish that the larger the egg the slower the development, and vice versa, but in Menidia we have an apparent exception for the egg is one of the smallest, yet the developmental period is practically as long as that of any species except Fundulus majalis.

Menidia menidia notata $\$ \times$ Fundulus heteroclitus $\sigma^{x}:$ June 22 and 29. The first experiment was performed without dissecting apart the egg masses and, although a large per cent of the eggs cleaved and developed, none went farther than late germ-ring stages. The second experiment was much more successful. The egg mass was carefully dissected apart so that many good embryos were isolated. These were in all stages of development from early germ-ring conditions to those in which embryos had lenses, otic vesicles, somites, etc. Only the more advanced embryos continued to develop normally, although the retarded individuals gained rapidly for a while, only to succumb after a day or two. None that were distinctly retarded at the time when the egg mass was dissected apart succeeded in completely recovering from the unhealthy conditions encountered before their isolation from the mass. Many embryos succeeded in developing a normal body with a pulsating 
heart, but established no circulation. These retarded hybrids show the most pronounced effects of the F. heteroclitus parent, not only in the presence of the squarish black chromatophores on the yolk and head, but in the possession of small but perfectly obvious red chromatophores on the yolk, a character totally foreign to the maternal species. Loeb noticed these red chromatophores in the same hybrid but expressed some hesitation in reporting their appearance, stating that they were the only paternal characters that he had noticed in heterogenic hybrids. On the fifth day six embryos established a circulation. In three the blood was abundant and in three scarce. The specimens with small blood supply died after two or more days. They showed scarcely any trace of paternal characters, no red pigment occurring on the yolk. Two embryos hatched, one in twelve and the other in fourteen days, or at about the same time as the pure bred Menidia embryos fertilized on the same date. These showed no paternal characters expect that there occurred on the head a smaller number of black chromatophores than is normal for Menidia. Being less crowded they spread into a larger area, giving the impression of being larger cells. At first I was inclined to interpret these chromatophores as a modified $F$. heteroclitus character but, when later the same conditions appeared in hybrids developed from Menidia eggs and the sperm of Poronotus and of Gasterosteus, I came to doubt the specificity of their inheritance. Moenkhaus made this cross three times but in no case did the embryos completely close the blastopore. The most successful of his embryos formed optic vesicles but got no farther. It is probable that a failure to dissect apart the egg masses accounts for his lack of success. Loeb also made this cross and reared advanced embryos that showed the red chromatophores of the paternal species. This case he cites as an exception to the rule that heterogenic hybrids are pure maternal.

Menidia menidia notata o $\times$ Fundulus majalis $\sigma^{\top}:$ June 30 and July 8. In both experiments nearly all of the eggs cleaved. The egg masses were dissected apart after about twenty-four hours, at which time there was already a considerable variation 
in the state of development of the different embryos. On the sixth day eight embryos were noted to have established a circulation, in one of which the vessels were so slender and the blood so scanty that life was maintained only for a day or two. The seven with normal blood supply lived and developed rapidly and five hatched on the fourteenth day. The two others never hatched but lived for several days longer. No trace of any paternal characters could be noted in these seven individuals but in some of the less successful embryos there was much less black pigment on body and yolk than was normal for the species. Since Fundulus majalis has rather delicately branched and widely separated chromatophores, this hybrid character might be interpreted as due to a paternal inheritance factor.

Menidia menidia notata $\& \times$ Cyprinodon variegatus $0^{\top}:$ July 1 . Only about 10 per cent of eggs cleaved. After twenty-four hours these were all in early periblast stages. Although these embryos were dissected apart they were all found to be undergoing disintegration on the second day, none having completed the closure of the blastopore.

Menidia menidia notata $\odot \times$ Gasterosteus aculeatus $\sigma^{7}: J u l y$ 4 and 9 . In the first experiment about 25 per cent of the eggs cleaved and were very early separated from the uncleaved eggs. The majority of the developing embryos completed gastrulation with the exception of the final closure of the blastopore. With the blastopore in the form of a slit-like opening a considerable number began to dedifferentiate but at least half of those that had entered upon the germ-ring stages successfully completed the closure of the blastopore and formed normallooking embryos. On the seventh day twelve individuals had established a circulation, which in some was rather feeble owing to scanty blood. On the thirteenth day six hatched. The other six, those with an imperfect blood supply, showed at this time signs of disintegration. Two of these showed a few red chromatophores in the tail region, a character quite foreign to pure Menidia but quite typical of Gasterosteus. This character is not visible in any of the hatched larvae. The black chromatophores on the heads of the latter are unlike those of pure Menidia 
in that they are fewer, larger, and exhibit a tendency to fuse. This difference from the pure-bred embryos cannot be definitely attributed to a specific Gasterosteus inheritance factor, for the same state of affairs was noted in the cross Menidia $\& \times \mathrm{F}$. heteroclitus $o^{x}$. The difference, however, is obvious and may be considered as a rather general hybrid effect common to several crosses with these eggs. The hatched larvae were not as viable as the pure bred, living only about half as long under the same conditions. In the second experiment the eggs were carefully observed for only three days, at which time they seemed to be destined to have the same end result as those in the first experiment. Not having time to see the experiment through it was abandoned.

Menidia menidia notata $q \times$ Apeltes quadracus or: June 21. A large proportion of the eggs cleaved normally and were dissected out of the egg mass. Only a very few safely passed the germ-ring stages, the majority stopping before the closure of the blastopore. Two however weathered the gastrulation period and grew to an advanced stage with well formed heads, pigmented eyes and pulsating hearts. As circulation was not established in either of these development ceased. The unusually dark-colored, heavy-bodied paternal type of chromatophore was obvious in both of the more advanced embryos but none of the red chromatophores characteristic of Apeltes were noted.

Menidia menidia notata $q \times$ Scomber scombrus or: July 1. Over 80 per cent of eggs cleaved normally, but at the next observation, about twenty hours later, they were all disintegrating in late periblast stages. We were especially anxious to repeat this experiment but were unable to obtain any more mackerel.

Menidia menidia notata $+\times$ Poronotus triacanthus or: June 30 and July 1. Although the first experiment showed a larger proportion of cleavages than the second, the two gave essentially the same result. The following description refers specifically to the experiment of June 30 . Over 75 per cent of the eggs cleaved. The egg mass was dissected apart at an early stage. Upon the sixth day five specimens had established a 
circulation. Many others had reached advanced stages but, without circulation, were unable to go on. On the fourteenth day three hatched into normal larvae which lived for several days. The other two in which circulation was noted had, at the same time, no heart beat and were dedifferentiating. Those that hatched had fewer and larger black head chromatophores than pure bred Menidia larvae. This is exactly the same situation as that noted in connection with the hybrids from Menidia eggs crossed with the sperm of $F$. heteroclitus and of Gasterosteus. In the second experiment only two embryos established a circulation and neither of them hatched.

Menidia menidia notata $q \times$ Stenotomus chrysops $\sigma^{n}:$ July 1 and 3. The first experiment went better than the second, although a comparatively small percentage of eggs was fertilized. One larva developed distinct lenses in the eyes, otic vesicles and many somites, but none established a heart beat and all were dead on the fourth day. In the second experiment a much larger per cent of eggs cleaved but, although dissected apart and well cared for, they all ceased to develop in early germ-ring stages or sooner.

Menidia menidia notata $\& \times$ Tautogolabrus adspersus $\sigma^{T}:$ June 24 and 25 . The two experiments were essentially identical in results. In one case about 40 per cent, and in the other case about 60 per cent, of the eggs cleaved. These developed normally at varying rates for three days and all succumbed during late germ-ring stages in which elongated embryonic axes were clearly defined.

Menidia menidia notata o $\times$ Tautoga onitis $\sigma^{7}:$ June 3 . This experiment resulted similarly to the one just described for Tautogolabrus. Moenkhaus made this cross and says of it that "the embryos were followed to the closure of the blastopore. The embryos were shorter than normal."

Although it has generally been supposed that Menidia eggs hybridize rather unsuccessfully, I have found that an increased measure of success is realized when the eggs are dissected apart from the mass in which they are stripped. I am inclined to believe that a number of the less successful experiments here 
recorded could be greatly improved upon if greater care were taken of the eggs and isolation of the embryos were accomplished during the earlier cleavages. In none of my experiments did I take the precaution of isolating the eggs at so early a period. A carefully conducted series of hybrid experiment with the eggs of this species would be well worth undertaking.

\section{CROSSES WITH THE EGGS OF SCOMBER SCOMBRUS}

It was a disappointment to us to obtain only one good lot of mackerel eggs. This species does not stand confinement and it was necessary for Mr. Larrabee to accompany the laboratory launch to the fish traps and to perform his hybridization experiment there. He had with him the males of only two other species, F. heteroclitus and Stenotonus chrysops. Several other attempts were made to secure mackerel eggs, but, although some eggs were obtained, they were either unripe or overdue. The mackerel egg is a handsome object, characterized by a faint pinkish tinge. Like other pelagic eggs it has one large oil globule. These eggs have a diameter greater than that of any other pelagic eggs worked with, averaging about $1.2 \mathrm{~mm}$. in diameter. Pure-bred embryos of this species develop well in finger bowls and hatch in less than three days as normal active larvae that live for several days in finger bowls. It was necessary to study the chromatophores of pure mackerel embryos and larvae in order to be able to judge of the paternal infiuence in crosses where the mackerel is the male parent. The characteristic points concerning the mackerel pigmentation are two. First the black chromatophores are exceedingly finely branched being more intricate and more delicate than those of any of the other species studied. Second there occur in certain definite places on the yolk and body large almost branchless green chromatophores, not found on any other species examined.

Scomber scombrus o $\times F$. heteroclitus or: June 30. A very large number of eggs were fertilized. Three simultaneous experiments were carried on in different vessels. The cleavage stages were perfectly normal though a little slower than in the 
case of the pure-bred egg. In late cleavages it was noticed that the blastoderm had become a little irregular in most of the embryos. Shortly afterward the blastoderms began to disintegrate without beginning gastrulation.

Scomber scombrus $\circ \times$ Stenotomus chrysops $\sigma^{7}:$ June 30. This experiment was begun and carried through in the same way as the one just described. The late cleavage stages were somewhat less irregular and a considerable number of embryos entered upon the period of gastrulation and went as far as the middle germ-ring stages in which a well-defined embryonic axis was noted. None however completely closed the blastopore.

It is to be hoped that more crosses with mackerel eggs will be made, for I do not consider the above experiments a fair test of their hybridizing powers. The eggs used in the experiments, however, must have been normal, for pure bred embryos fertilized at the same time from eggs taken from the same females developed normally and hatched.

\section{CROSSES WITH THE EGGS OF STENOTOMUS CHRYSOPS}

The eggs of the scup were obtained in good condition only twice but each time in great abundance. Like other pelagic eggs they go bad quickly unless stripped shortly after ripening. Females caught in nets and confined overnight or kept in live-boxes are prevented from spawning and their eggs deteriorate. Many females were secured in which the eggs though present in large quantities were all dead and disintegrating. The scup egg is among the smallest of those used in these experiments, averaging about $0.8 \mathrm{~mm}$. in diameter. It is colorless and very transparent having one large oil drop. Embryonic development is rapid, the larvae hatching in less than fortyeight hours after fertilization. The larvae are incapable of living more than a day or two in finger bowls. Doubtless death is due to starvation and confinement. On hatching the larvae are very sparsely pigmented. Two kinds of chromatophores occur, one a very delicately branched black type confined to the body, and a roundish opaque yellow type occurring in definite 
places about the body, one pair in front of and one pair behind the eyes; a third pair behind the otic vesicles and a number of less regularly arranged pairs on body and tail. Success in rearing pelagic egg hybrids depends on the care with which the living eggs are kept free from the decaying ones. It is my custom to skim off all the eggs found floating at the surface and to transfer them to fresh water. This, if done several times a day, gives very satisfactory results, for by this method I have been able to rear to hatching hybrids from scup eggs crossed with sperm of almost all of the species tried.

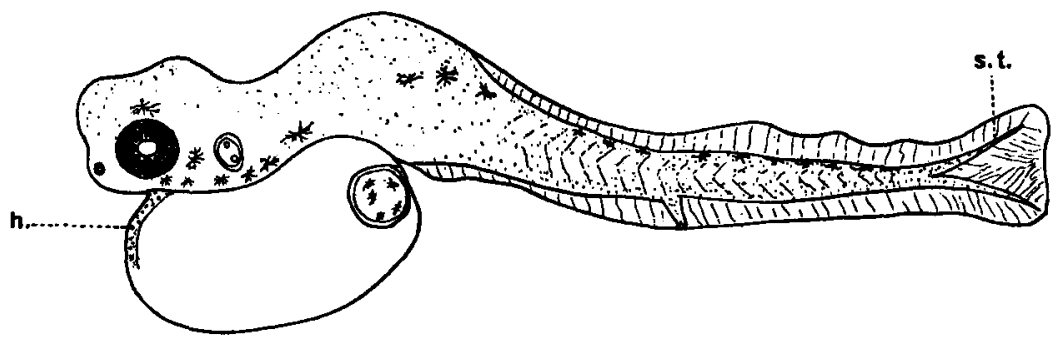

Fig. 9 Hump-backed, double-tailed hybrid larva (just hatched at three days) from Stenotomus chrysops $q \times$ Fundulus heteroclitus $\sigma^{7}$. The heart $(h)$ was beating vigorously, and split tail (s.t.) was used vigorously in swimming.

Stenotomus chrysops $\& \times$ Fundulus heteroclitus $\sigma^{\top}:$ June 26 and July 1. In the first experiment about 25 per cent of the eggs cleaved. A large proportion ceased to develop during gastrulation stages. After twenty-four hours about forty living embryos were skimmed off and were well cared for. Among the embryos that were living at this time there occurred a number of well defined abnormal types including cyclopians and individuals showing spinal bifida. After forty-six hours about twenty-five embryos were still living. A majority of these appeared to be abnormal, but in ten the heart was beating and a circulation established. At fifty-two hours two had hatched and were swimming about. These, although apparently healthy were hump-backed and one had a double tail (fig. 9). Both were found dead after three hours. This result was decidedly in contrast with the control, in which very large numbers of 
perfectly normal larvae were produced. The second experiment gave results exactly like those just described, except that fewer eggs reached advanced stages. Six larvae hatched and were quite normal, living for at least twenty-four hours after hatching. I have been unable to note any Fundulus influence in this cross; it seems to be pure maternal in character.

Stenotomus chrysops $+\times$ Fundulus majalis $\sigma^{\top}:$ June 26. About 50 per cent of the eggs cleaved normally but the great majority of these succumbed during early gastrulation periods. The few that survived this period developed for forty-eight hours, forming advanced larvae with the head parts well differentiated but with rudimentary tails; none established circulation.

Stenotomus chrysops $\& \times$ Apelles quadracus $\sigma^{7}$ : June 26. About 10 per cent of the eggs cleaved, nearly half of which stopped at the end of the cleavage period. The others completed gastrulation and developed into embryos with optic cups and rather vague lenses and a number of indefinite somites. After about thirty hours all embryos appeared to be disintegrating.

Stenotomus chrysops of $\times$ Menidia menidia notata or: June 26 . This experiment resulted almost exactly like that described above for the F. majalis hybrid.

Stenotomus chrysops $\& \times$ Scomber scombrus o $^{x}:$ July 1 . Over 80 per cent of eggs cleaved and developed normally through the cleavage period. After twenty-five hours an unusually large proportion of the embryos were alive and developing. Many of these showed the green chromatophore characteristic of the mackerel. As many as thirty hatched but only a few were normal in appearance. Others exhibited various deformities of body and tail. Conspicuous among the latter was a coiledtail defect; all of those that hatched died in a few hours.

Stenotomus chrysops $\circ \times$ Poronotus triacanthus $\sigma^{7}$ : June 6 and July 1. In the first experiment nearly 100 per cent of eggs cleaved and none showed evidences of polyspermy. After twenty-two hours only very few were alive and floating on the surface. These were in later germ-ring stages or with the blastopore just closed and the embryo developing optic vesicles. At 
forty-six hours only two were still alive; these seemed to be far enough along to hatch but showed no circulation; both died without hatching. In the second experiment about 40 per cent of eggs cleaved normally and of these the majority entered upon the gastrulation period. After forty-eight hours between forty and fifty embryos had established a circulation. At sixty-five hours over twenty individuals had hatched and were for the most part alive and active. A few crooked-bodied individuals had hatched but were dead or dying when first seen. The hatched embryos seemed to be exactly like the pure scup larvae except that they hatched with a larger amount of undigested yolk. Many of these larvae were alive after two days, which is as long as pure bred larvae will live under the same conditions.

Stenotomus chrysops $\% \times$ Tautogolabrus adspersus $\sigma^{7}:$ June 26. Nearly 100 per cent of eggs fertilized. When compared with the control five hours after fertilization there was a very pronounced difference in the stage of development, there being almost twice as many cells in the pure as in the hybrid embryos. After twenty-two hours about 90 per cent of the embryos had died. After thirty hours a very few embryos were skimmed off and examined. These had apparently reached their maximum development. None of them had successfully closed the blastopore although considerable embryonic development had taken place. Well defined optic vesicles and a few somites were present, but the germ-ring, instead of closing to form the blastopore, had undergone a looping process quite different from anything observed in any other cross.

\section{CROSSES WITH THE EGGS OF TAUTOGOLABRUS ADSPERSUS}

The results of these experiments are very similar to those with scup eggs. The average size of the cunner egg is a little greater than that of the scup, being about $1 \mathrm{~mm}$. in diameter. As in the scup, the eggs deteriorate quickly if the fish are kept in the laboratory. The incubation period varies with the temperature, from two to three days. The larvae do not live well in finger bowls. 
Tautogolabrus adspersus $\odot \times$ Fundulus heteroclitus or: June 14 and July 3. In both experiments large numbers of eggs cleaved and development was normal through the cleavage period and during the early stages of gastrulation. None, however, succeeded in completing gastrulation although embryos with optic vesicles were not uncommon. Moenkhaus made this cross but once and followed it only to the sixteen-cell stage. Miss Morris claims to have reared this cross for twenty-four hours, but does not mention the degree of development attained.

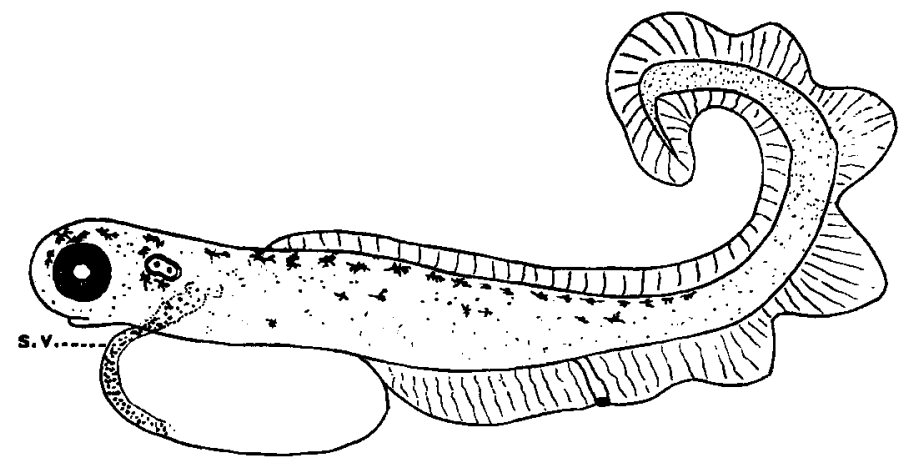

Fig. 10 Hatched hybrid larva from Tautolabrus adspersus $q \times$ Fundulus majalis $\sigma^{7}$. Note the partially spiral tail found commonly in hybrid larvae; the sinus venosus on the yolk (s.v.) was well filled with blood and the circulation was good.

Tautogolabrus adspersus $+\times$ Fundulus majalis $\sigma^{7}:$ June 25. About 30 per cent of eggs cleaved normally, a majority of which developed through the gastrulation stages and formed advanced embryos. Eight individuals established a circulation. On the third day two hatched both of which were abnormal in appearance with twisted tails and median fins oddly notched and wrinkled (fig. 10). They lived for only a few hours and showed no distinct evidences of paternal inheritance factors.

Tautogolabrus adspersus o $\times$ Apeltes quadracus or: June 25. Only about 5 per cent of the eggs cleaved but nearly all of these developed well through the gastrulation period and twelve established a circulation. Of these eight hatched, all being more 
or less abnormal. One that seemed most nearly normal differed from the pure cunner in the possession of a much shorter tail, a larger yolk sac, and a rather pronounced lack of pigment. This is the opposite of what one might expect, as Apeltes quadracus is the most heavily pigmented of the species used.

Tautogolabrus adspersus $\& \times$ Menidia menidia notata $\sigma^{T}$ : July 3. About 80 per cent of the eggs cleaved and nearly all began the process of gastrulation, but none succeeded in closing the blastopore. All stages in germ-ring formation were noted. Some of the embryos showed a considerable amount of head differentiation, brain vesicles and optic vesicles being distinctly defined. In all the more advanced embryos the blastopore was oval or slit-like in form.

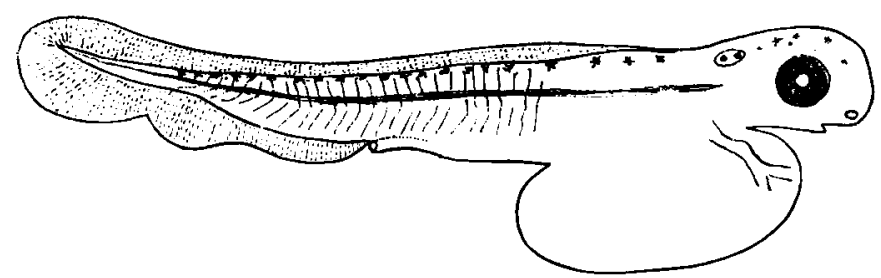

Fig. 11 The nearly normal, hatched larva from Tautolabrus adspersus $q \times$ Apeltes quadracus $\sigma^{7}$; the body is somewhat shorter than in pure bred cunner larvae.

Tautogolabrus adspersus $\odot \times$ Menidia beryllina cerea $\sigma^{x}:$ July 3. About 50 per cent of the eggs cleaved, some quite irregularly due probably to polyspermy. A large number entered upon the gastrulation period. About twenty succeeded in closing the blastopore. After three days ten or more were still alive and appeared to be ready to hatch. None, however, succeeded in hatching probably on account of lack of vitality. Careful examination showed various rather pronounced abnormalities in these specimens. In a number of them the notochord was badly distorted and twisted and the brain vesicles were bent and asymmetrical. In many the somites were ill defined. Although a circulation had been established at an earlier period the heart had ceased to beat when this last observation was made. 
Tautogolabrus adspersus $\& \times$ Poronotus triacanthus $\sigma^{7}:$ July $S$. About 30 per cent of the eggs cleaved. Only a few individuals weathered the gastrulation period. Eight established a circulation and six hatched as normal active larvae that showed practically pure maternal characters and lived for from one to four days.

Tautogolabrus adspersus $\circ \times$ Morone americana $\sigma^{T}:$ June 25. About 25 per cent of eggs cleaved normally of which a large proportion completed gastrulation and fourteen established a circulation. Four hatched, one of which lived for a day or two, the others dying in about three hours. No data on inheritance taken.

Tautogolabrus adspersus $+\times$ Stenotomus chrysops $\sigma^{T}:$ July 4. thout 80 per cent of eggs cleaved. About 200 passed the period of gastrulation and formed advanced pigmented embryos. It was expected that a very large proportion of these embryos would hatch but only about forty did so. The majority of these embryos were normal but others were twisted and deformed in various ways. Among the embryos that failed to hatch but were living on the third day were noted examples of most of the well known types of monsters, including cases of cyclopia, heterophthalmia, uniophthalmia, anophthalmia, dicephalia, spina bifida, microcauda and many other deformities. A great many specimens were found that had partially hatched, a tail being thrust out of the egg membrane but the body being still enclosed. Any one interested in the study of monsters would find this cross excellent material for investigation.

\section{CROSSES WITH THE EGGS OF TAUTOGA ONITIS}

The Tautog egg is, so far as size and appearance go, identical with that of the cunner but in ability to hybridize it differs very materially from the latter. Although the eggs used were evidently in good condition, as evidenced by the fact that the pure bred larvae hatched in large numbers, none of the crosses succeeded in completing the process of gastrulation. All the crosses were made from the eggs of one large female and gave 
practically identical results in each case. The following species were used as sperm parents: Tautoga onitis, Fundulus heteroclitus, Menidia menidia notata, Poronotus triacanthus, and Tautogolabrus adspersus. Whether or not the eggs of the Tautog are always as unsuccessful in crossing remains to be seen. We were unable to obtain good eggs of this species a second time. Moenkhaus describes a cross between Tautoga onitis and Menidia menidia notata in which all embryos died before or during germ-ring stages. In some the germ-ring had spread about two-thirds over the yolk.

\section{DISCUSSION OF DATA}

Success in development and systematic relationship

A survey of the results of these crosses shows that a large percentage of even the most heterogenic hybrid strains produce embryos with circulation and that a somewhat smaller percentage give rise to active free-swimming larvae. A list of those crosses in which a circulation was established or larvae hatched will be useful for reference (table 2). Of these crosses thirteen are between two different orders, four between different suborders of Acanthopterygii, and one between two families of the sub-order Rhegnopteri. This is the first time that heterogenic Teleost hybrids have been reared to hatching. I am unable to offer an explanation of the failure of other workers to get similar results, but I am convinced that even better results can be obtained by any one who will take reasonably good care of the embryos. There appears to be no reason to doubt that certain of the hybrid larvae could be reared in aquaria and, if properly cared for and fed in orthodox fashion, carried on to maturity. The data here given seem to furnish a distinct argument against the idea that success in development of hybrids is correlated with the nearness of relationship of the species used. Particularly does this idea fail when it is recalled that a considerable number of homogenic crosses exhibit much less success in developing advanced embryos than many of these most heterogenic strains. Further light may be thrown upon this point 
TABLE 2

\begin{tabular}{|c|c|c|}
\hline SPECIEB CROAGED & $\begin{array}{c}\text { CIRCULATION } \\
\text { ESTABLIBH ED } \\
\text { IN } \\
\end{array}$ & NUMBER HATCHMD \\
\hline 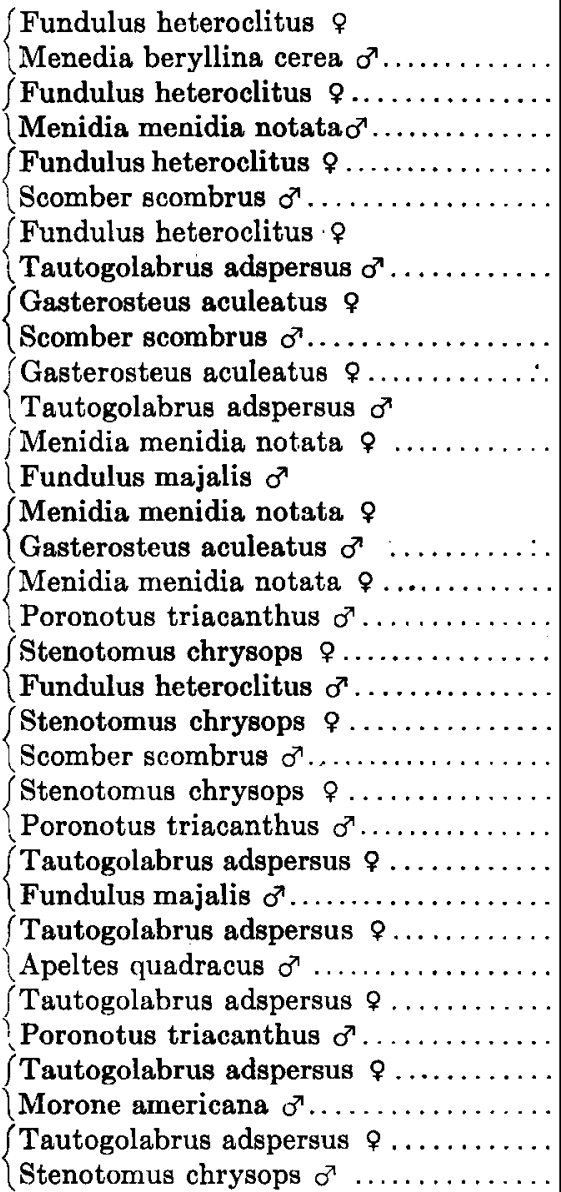 & $\begin{array}{r}2 \\
8 \\
12 \\
5 \\
10 \\
50 \\
40 \\
8 \\
12 \\
8 \\
14\end{array}$ & $\begin{array}{l}\mathbf{5} \\
\text { lived } 3 \text { weeks } \\
1 \\
\text { lived } 3 \text { weeks } \\
1 \\
1 \\
\text { lived } 10 \text { days } \\
\\
\quad 5 \\
\quad 6 \\
\quad 3 \\
\text { lived several days } \\
2 \\
\text { died in a few hours } \\
25 \\
\text { lived from } 2-12 \text { hours } \\
20 \\
\text { lived about } 2 \text { days } \\
2 \\
\text { lived only few hours } \\
8 \\
\text { lived } 2 \text { days } \\
6 \\
\text { lived 1-2 days } \\
4 \\
\text { lived } 2-4 \text { hours } \\
40 \\
\text { about } \\
\text { lived } 2-24 \text { hours }\end{array}$ \\
\hline
\end{tabular}

by an examination of a long list of unsuccessful heterogenic crosses, those that did not survive beyond the germ-ring stages. In table 3 appears the list of these crosses, given in the order in which they appear in the descriptive part of the paper. One should, however, especially note the fact that in all these crosses, except that between Fundulus heteroclitus $q \times$ Tautoga onitis 
DEVELOPMENT AND HEREDITY IN HYBRIDS

TABLE 3

\begin{tabular}{|c|c|}
\hline EGG PARENT & BPERM PARENT \\
\hline Fundulus heteroclitus. & $\left\{\begin{array}{l}\text { Morone americana } \\
\text { Tautoga onitis }\end{array}\right.$ \\
\hline Fundulus diaphanus.......... & $\left\{\begin{array}{l}\text { Poronotus triacanthus } \\
\text { Stenotomus chrysops } \\
\text { Tautogolabrus adspersus }\end{array}\right.$ \\
\hline Fundulus majalis............ & Apeltes quadracus \\
\hline Cyprinodon variegatus........ & $\left\{\begin{array}{l}\text { Apeltes quadracus } \\
\text { Menidia menidia notata } \\
\text { Scomber scombrus } \\
\text { Stenotomus chrysops } \\
\text { Tautoga onitis }\end{array}\right.$ \\
\hline Gasterosteus aculeatus....... & $\begin{array}{l}\text { Fundulus diaphanus } \\
\text { Fundulus diaphanus }\end{array}$ \\
\hline Apeltes quadracus............ & $\left\{\begin{array}{l}\text { Cyprinodon variegatus } \\
\text { Menidia menidia notata } \\
\text { Poronotus triacanthus } \\
\text { Stenotomus chrysops }\end{array}\right.$ \\
\hline Menidia menidia notata & $\left\{\begin{array}{l}\text { Cyprinodon variegatus } \\
\text { Scomber scombrus }\end{array}\right.$ \\
\hline Scomber scombrus $\ldots \ldots \ldots \ldots$ & $\left\{\begin{array}{l}\text { Fundulus heteroclitus } \\
\text { Stenotomus chrysops }\end{array}\right.$ \\
\hline Tautogolabrus adspersus & $\begin{array}{l}\text { Menidia menidia notata } \\
\text { Fundulus heteroclitus }\end{array}$ \\
\hline T'autoga onitis....... & $\left\{\begin{array}{l}\text { Menidia menidia notata } \\
\text { Menidia beryllina cerea } \\
\text { Poronotus triacanthus }\end{array}\right.$ \\
\hline
\end{tabular}

$\sigma^{7}$, only one experiment was carried out. It is highly probably that had several experiments been made with each cross some of those listed here would have to be transferred to table 2, but, making due allowance for the likelihood that a considerable number of these crosses would result in more advanced stages if repeated a number of times, it is likely that a very large residue of unsuccessful crosses would remain. Of these least successful crosses here listed twenty are between different orders, four between different sub-orders of Acanthopterygii, and two between different families of the same sub-order. These proportions do not differ materially from those that held for the most successful crosses. In other words, it would appear that 
among heterogenic crosses success in development is not correlated with the nearness in relationship of the two species used. Even when we consider homogenic crosses it is found that certain hybrid types, as for example those between Cyprinodon and the various Fundulus species (Newman '14), are decidedly unsuccessful. These two genera, nevertheless, are closely allied members of the same family, the Poeciliidae. I was never able to get any of these crosses to develop beyond gastrulation. Furthermore, it is not even always true that crosses between two species of the same genus develop as successfully as do some of the most heterogenic crosses. It is well known, for example, that when the eggs of Fundulus majalis are fertilized by the sperm of $\mathrm{F}$. heteroclitus or $\mathrm{F}$. diaphanus, no embryos hatch and many of them fall far short of this stage. Contrast this situation with the fact that so many crosses between distinct orders give a fair number of viable larvae and large numbers of advanced embryos and it will become evident that we must look to some other factors than those involved in systematic relationships for an explanation of the varying degree of success in the development of hybrid embryos.

\section{Factors governing success in development of teleost hybrids}

Among the most striking general facts that arise out of the data given above are: that the eggs of some species never hybridize well, while those of others appear to have a high capacity for crossing with almost any other species. The eggs of $F$. majalis, for example, develop poorly even when fertilized with the sperm of a closely allied species of the same genus, for I have never seen a hybrid larva hatch from the egg of this species. A glance at the other crosses with F. majalis eggs shows that none of the heterogenic hybrids even develop a circulation. In fact most of these hybrids ceased to develop in the germ-ring stages. In other papers (Newman '08, '14) the ill success of majalis egg hybrids was attributed to the large size of the egg and the indigestibility of the yolk. There is apparently something about the yolk of this egg that renders it difficult material for hybrid 
embryos to break down. It evidently digests slowly even in pure-bred embryos for it requires three weeks or more for them to hatch. No success was obtained with heterogenic hybrids from the eggs of F. diaphanus. Since, however, I had so few eggs and made only one experiment on each of the few crosses tried, I do not care to lay much stress upon the results here recorded. I am convinced, however, that even under the best conditions it will be found that this species hybridizes much less successfully than its nearest relative F. heteroclitus. Cyprinodon seems to furnish another example of a species the eggs of which cross badly with even its closest relatives. I have never observed an advanced hybrid embryo derived from a Cyprinodon egg although these eggs fertilize and cleave normally for a considerable time. The eggs of Apeltes give results that remind one strongly of those obtained with the eggs of $F$. majalis, for they cross poorly even with the most closely related species, Gasterosteus, and in heterogenic crosses they never go beyond an early embryonic stage. These eggs are of the same size and are laid in the same way as those of Gasterosteus yet there is a very marked difference in the developmental success of these two species of Gasterosteidae. The only notable difference between the eggs of these two species is in the color of the yolk, that of Apeltes being brownish amber and that of Gasterosteus being a much lighter yellow. The color difference is doubtless associated with density as well as with chemical composition. The darker, more opaque, yolk of Apeltes is evidently harder to digest than the lighter more transparent yolk of Gasterosteus and is therefore less favorable material for hybrid development.

Although some pelagic eggs such as those of the scup and cunner hybridize very successfully, others, as those of the Tautog and the mackerel have poor success. I would not be willing, however, to go on record as predicting that the degree of success described represents the maximum of success obtainable with these crosses, for only one lot of good eggs of each of the last two species was obtained. It cannot then be said that mere egg size is a controlling factor in determining the success of development in hybrids, although in general it seems to be true 
that small eggs with little yolk hybridize better than large eggs with voluminous yolk. The three species that hybridize with the largest degree of success have small eggs: those of Tautogolabrus, Stenotomus and Menidia. Of these the first two are pelagic and the last is a type laid on or near the bottom. The eggs of Menidia would, I am convinced, hybridize very much more successfully if they could be scattered when they are stripped instead of being bunched into dense masses. This tendency to form egg aggregates is a mere mechanical factor which has nothing to do with the hybridizing capacity of the species, yet may very materially affect the results. I am inclined to believe that, making due allowance for this mechanical hindrance, the eggs of Menidia cross more successfully than those of any others species here dealt with. Considering the rather large size of the eggs of Fundulus heteroclitus and the fact that they, like those of Menidia, have a tendency to adhere in bunches, these eggs hybridize with rather marked success. For crosses produced respectively with the sperm of Menidia beryllina cerea, Menidia menidia notata, Scomber scombrus, and Tautogolabrus adspersus, give embryos in which the circulation is established and, with the exception of the first cross, produce larvae. Only one out of eleven heterogenic crosses with the eggs of this species failed to develop fairly advanced embryos. F. heteroclitus eggs are well known to be extraordinarily hardy, thriving even under the most adverse conditions. Normal larvae have been known to exist even in the foulest sea-water and to thrive in fresh as well as in brackish water. It is probably in consequence of the hardiness of these eggs that hybrid larvae derived from them develop so well and reach such advanced stages; for a robust egg could conceivably overcome the difficulties involved in inharmonious germ plasms. In view of these facts the conclusion seems to be justified that the chief factors making for success or failure in hybrid development are associated with certain specific characters in the egg, of which amount, composition and density of yolk, hardiness or delicacy, and certain mechanical advantages or disadvantages, play a leading rôle. 
There are certain indications also that some species of sperm are better adapted to hybridization than others. The sperm of $\mathrm{F}$. heteroclitus, for example, as well as that of both species of Menidia and of Poronotus give a much better set of hybrids than does that of Stenotomus, of Cyprinodon or of Tautoga. This difference is not correlated with the amount of milt or with the freedom with which it may be stripped. There must be then some specific peculiarity that renders certain sperm good for hybridization and others bad. Possibly the size of the sperm head may be a factor but there are no data on this point. One of the respects in which Teleosts differ most widely is in the rate of development. Some species develop to hatching in two days and others require three weeks or more. One would be inclined to expect $a$ priori that when two species with the same developmental rate are crossed we would obtain a more harmonious end result than when two species with a very different rate are used. This is true, however, only to a very limited extent. The various species of pelagic eggs which hatch in two or three days unquestionably hybridize together with more general success than do these species when crossed with forms that have a slow developmental rhythm. But there are cases which seem to form an exception to this rule. Menidia eggs, for example, although requiring two weeks for development, hybridize well with Poronotus, which hatches in about two days; Fundulus heteroclitus hatching in two weeks crosses successfully with Scomber scombrus which hatches in two to three days. Again, the eggs of Scomber scombrus (hatching in two to three days) do not develop beyond the germ-ring stages when crossed with Stenotomus which has the same developmental rhythm. On the other hand, Fundulus heteroclitus and Menidia menidia notata, both of which have about the same developmental period (approximately two weeks), produce viable larvae from both reciprocal crosses although they represent two distinet orders.

We may conclude then that success in hybrid development is not correlated with nearness of relationship but with certain specific 
characters of the germ cells, especially of the eggs, of which yolk: composition is probably the most important and rate of development of secondary significance.

Factors governing the differences in success of reciprocal crosses

It has been noted by many writers that reciprocal crosses differ not only in success of development but also in rate of development and in inheritance. The extensive array of reciprocal crosses here described furnishes material of importance for the solution of the problems involved in this situation. In table 4 are listed all the heterogenic crosses that are reciprocal. A

TABLE 4

\begin{tabular}{|c|c|}
\hline EGG PARENT & SPERM PARENT \\
\hline Fundulus heteroclitus... & $\left\{\begin{array}{l}\text { Menidia menidia notata } \\
\text { Gasterosteus aculeatus } \\
\text { Apeltes quadracus } \\
\text { Stenotomus chrysops } \\
\text { Scomber scombrus } \\
\text { Tautogolabrus adspersus } \\
\text { Tautoga onitis }\end{array}\right.$ \\
\hline Fundulus diaphanus........... & $\left\{\begin{array}{l}\text { Menidia menidia notata } \\
\text { Apeites quadracus }\end{array}\right.$ \\
\hline Fundulus majalis... & $\left\{\begin{array}{l}\text { Menidia menidia notata } \\
\text { Stenotomus chrysops }\end{array}\right.$ \\
\hline Cyprinodon variegatus........ & $\left\{\begin{array}{l}\text { Menidia menidia notata } \\
\text { Gasterosteus aculeatus } \\
\text { Apeltes quadracus }\end{array}\right.$ \\
\hline Gasterosteus aculeatus.. & $\left\{\begin{array}{l}\text { Menidia menidia notata } \\
\text { Tautogolabrus adspersus }\end{array}\right.$ \\
\hline Apeltus quadracus............ & $\left\{\begin{array}{l}\text { Menidia menidia notata } \\
\text { Stenotomus chrysops }\end{array}\right.$ \\
\hline Menidia menidia notata....... & Stenotomus chrysops \\
\hline
\end{tabular}

review of these crosses shows that there is not always a marked difference in success of reciprocals. For example, Fundulus heteroclitus and Menidia menidia notata cross equally well both ways. The same is true for the last cross listed, Stenotomus by Tautogolabrus. Certain other reciprocals go badly both ways, as for example F. heteroclitus by Tautoga and Cyprino- 
don by Apeltes. Certain others go moderately well both ways as F. heteroclitus by Gasterosteus and F. heteroclitus by Apeltes. The majority of these crosses show a marked difference in the developmental success of reciprocals. All the crosses involved with Fundulus majalis were less successful when the egg of this species was used than when $F$. majalis was the male parent. The same was true also for Cyprinodon which gives exceedingly poor results when its eggs are used but makes a number of successful combinations when its sperm is employed. The reverse is in general true for Stenotomus which gives better results when used as the egg parent than as the sperm parent.

Thus we are led to the inevitable conclusion that this difference between reciprocals is dependent upon the general hybridizing capacities, irrespective of systematic relationship, of the two types of parental germ cells used. When for example two species are crossed, the egg of one of which had a high and the other a low capacity for hybridizing, we expect the hybrid from the better egg to develop more successfully than that from the poorer egg. A concrete case is furnished by the cross between Fundulus majalis with a large egg that has a low hybridizing capacity, and Menidia a species with a small egg of marked hybridizing capacity. The result is that the F. majalis egg hybrid ceases to develop in germ-ring stages, while the Menidia egg hybrid produces a number of viable larvae. As was found to be true for crosses in general, the underlying cause for differences in developmental success of reciprocal crosses has its seat in the nature and amount of the yolk and has nothing to do with the relationship.

\section{Inheritance in heterogenic hybrids}

In a recent paper Loeb ('12), after a study of a few Teleost crosses derived chiefly from the egg of Fundulus heteroclitus, comes to the conclusion: "that the formation of the embryo is purely a matter of the egg and that the main function of the spermatozoön is the causation of the development of the egg. If we may express this statement in the form of a paradox we 
may say that fertilization is primarily and essentialy artificial parthenogenesis." This radical conclusion was reached as the result of observations on the inheritance of chromatophores in heterogenic hybrids. In all the hybrids made with the eggs of Fundulus heteroclitus Loeb sees only the maternal types of chromatophore. This species has two types of these pigment cells, black and red, and these occur on both body and yolk. Now black chromatophores are common to all Teleost embryos, and red cells occur in a number of the species that I have dealt with. The specific differences lie in peculiarities of branching, in tendencies to fuse or to remain separate and in other minor characters. One has to become very familiar with the specific peculiarities of these chromatophores in order to be able to judge of their inheritance. Each type has its own developmental history and each is much more generalized (less specific) in form during the early stages than after it has reached the definitive condition. The definitive black chromatophores of F. heteroclitus are large polygonal bodies unlike those of any other species observed. They exhibit only a slight tendency to branch and a strong tendency to fuse in groups. Chromatophores with long slender branches are totally foreign to the healthy F. heteroclitus embryo. Branching, however, may be induced experimentally by adding a small amount of $\mathrm{NaCN}$ to the sea water as was shown by Loeb. Although it must be admitted that chromatophores can be made to branch under the influence of certain chemicals I have never noted this condition in even the unhealthy pure-bred larvae reared under laboratory conditions. Consequently, when in certain hybrid embryos a well defined type of branching chromatophore appears either to the exclusion of the polygonal type or side by side with the latter, its occurrence cannot be adequately explained as the result of ill health in the embryo due to deleterious effect of foreign germ plasm. In many ways the chromatophores would seem to furnish unsatisfactory material for the study of paternal and maternal inheritance, because these structures are so variable in habit. One must therefore rely for a demonstration of paternal influence upon certain cases that are beyond the range 
of controversy. The following are some of the heterogenic crosses in which there is positive proof of the foreign spermatozoön playing a rôle in heredity. The case of Menidia menidia notata $q \times$ Fundulus heteroclitus $\sigma^{7}$ was cited by Loeb as follows:

While it is the rule that in the case of heterogeneous hybridization heredity is purely maternal it is possibly not without exception. I have, however, thus far found only one paternal characteristic that is possibly transmitted to a hetrogeneous hybrid. The yolk sac of Funulus heteroclitus forms branched red chromatophores which are not found on the yolk of Menidia. In two eggs fertilized by the sperm of Fundulus heteroclictus a few red chromatophores were observed. It is difficult to get this cross and I give this observation with some hesitancy.

I have obtained this cross several times and could have made it as often as I wished, for the two species were spawning through most of June and July and hybridized well together. I am able to confirm Loeb's observation of red chromatophores on the yolk of the Menidia egg hybrid. They occur in many embryos that reach a moderately advanced condition but seem to be lacking in the most successful embryos, which are nearly pure maternal. Perhaps the best cross to show paternal heredity is that resulting from $F$. heteroclitus $q \times$ Scomber scombrus $\sigma^{7}$. These two species have chromatophores of as distinct and opposite types as possible. The blacks and reds of $F$. heteroclitus have been described. The mackerel has a black type of extreme delicacy with scarcely any body to the cell and with many slender branches, and a highly characteristic and quite unique green type. Now in many of the moderately successful hybrid embryos, chromatophores, of the squarish sort characteristic of $F$. heteroclitus, lie side by side with those of the finely branching type characteristic of the mackerel. In other hybrids the body of certain chromatophores may be of the pure heteroclitus type but this body may give off one or more long branches of the delicate sort characteristic of the mackerel. Loeb believes that the modified chromatophores of heterogenic Fundulus egg hybrids are due to lack of oxygen, but it is hardly likely that the oxygen conditions are so different for two adjacent cells as 
to make one assume the finely branching form and leave the other unchanged.

We must conclude then that the condition here presented is to be interpreted as a mosaic of paternal and maternal inheritance units. No more remarkable example of paternal influence in heterogenic crosses could be asked for than that seen in connection with the green and the red chromatophores of the two species in question. Remembering that the green type never occurs in $F$. heteroclitus and that the red type always occurs in this species, it is startling to find in a considerable number of the hybrids from F. heteroclitus $\%$ and Scomber scombrus $o^{7}$ unmistakable green chromatophores, and in others a total lack of red yolk chromatophores. The embryos that lack red cells have, in addition, no blacks of the F. heteroclitus type, but show a fine network of branching chromatophores all over the yolk. Here we have then the transmission of a positive paternal character on the one hand, and the suppression of a positive maternal character on the other, neither of which can be explained on any other basis than that the foreign spermatozoön exercises an hereditary influence and that, therefore, Loeb is wrong in supposing that this kind of development is purely maternal and essentially parthenogenetic. Many other evidences of paternal heredity are cited in the description of different crosses and need not be recapitulated here. It is commoner to find paternal characters in heterogenic crosses than to note its absence.

The findings of Moenkhaus, of the Hertwigs, and of Miss Morris, that there is no elimination of chromatin in heterogenic Teleost hybrids, are in line with the revelations of this paper concerning the influence of the paternal element in heredity. In most cases the maternal influence is more pronounced than the paternal but perhaps we should expect this because of the larger deutoplasmic contribution of the egg. But there is nearly always a series of embryos ranging from those showing a very marked paternal dominance to those showing little or no trace of it. As a gen eral rule I have found that when the paternal influence is strong the embryo fails to reach its maximum developnicnt and that all or nearly all of the most successful hybrids are 
predominantly maternal. In a number of cases hybrid larvae differ in their inheritance characters from the pure bred larvae but the differences are of a generalized character not definitely referable to the paternal species. This is true of the hybrids from Menidia menidia notata eggs and the sperm of $\mathrm{F}$. heteroclitus, Poronotus and Gasterosteus. In all three of these hybrid strains the hatched larvae show a few large solid chromatophores on the head instead of the numerous branching bodies characteristic of the Menidia larvae. This difference between pure and hybrid forms is very striking but I do not understand its significance.

It seems to be true, within limits, that only the most successful hybrids are preponderent maternal and that the less successful larvae in nearly all heterogenic crosses show a duality of parents. It may be that when the paternal influence is largely suppressed there is less disharmony in development and therefore a better chance for the hybrid to go through the critical periods of development without suffering from the discord between opposed parental tendencies. Even in the larvae, however, that are phenotypically pure or nearly pure maternal, there is doubtless carried latent or recessive in the germ plasm the full complement of paternal inheritance factors, that would segregate out in the following generation, if it were possible to interbreed the $F_{\mathfrak{t}}$ hybrids. We are therefore not dealing with a case of parthenogenetic development but with one involving a more or less complete dominance of the egg over the sperm.

\section{Hybridization and the occurrence of monsters}

Very many of the types of monsters that have been described in experimental and embryological literature occur with great frequency in hybrid strains. Cyclopic, uniophthalmic and anophthalmic monsters are of frequent occurrence. All grades of spina bifida and dicephalia occur. Double and triple tails are common as are headless and tailless forms; but none of these characters are to be attributed to the specific influence of the male parent. They are rather generalized pathological conditions due to mechanical or chemical retarding agents some of 
which may result from a disharmonious interaction of foreign germ plasms. Some conditions however are strikingly specific for certain crosses. Perhaps the most pronounced case of this sort is that seen in the cross Fundulus heteroclitus $q \times$ Poronothus triacanthus $\sigma^{\top}$. Here the embryos that developed most successfully are all narrow-headed. In rare cases the head may differentiate rather extensively but it always remains much too small and narrow for the body. This situation suggests some specific influence of the male cell in embryo formation. Again, to cite an opposite case, in the cross Apeltes quadracus o $\times$ Menidia beryllina cerea $\sigma^{x}$ there occurred very peculiar specific deformities. The head developed on one side of the yolk and tail at a distance on the other. This condition occurred in nearly all advanced embryos. At first I thought $I$ had a case of polyembryony but found later that the condition is due to the fact that the mid-region of the body fails to develop, leaving the two extremities separate. This again indicates some specific influence of the male cell in embryo formation. Many other similar cases are cited in connection with the various crosses which tend to show that abnormalities in particular crosses may be more or less specific and not merely general pathological conditions.

\section{Developmental blocks in heterogenic crosses}

It seems to be generally true that the developmental rate of heterogenic crosses is slower than that of the pure bred maternal species. The retarding influence of the foreign sperm manifests itself during early cleavage in some crosses, during late cleavage in others, and not until gastrulation in still others. Appellöf calls attention to a well defined early retardation in the cross between Spinachia $\& \times$ Gasterosteus $\sigma^{7}$, in which case the hybrid eggs were in the 4-cell stage when the pure bred Spinachia eggs were in 8-cell stages or farther. Moenkhaus cites a series of cases of early retardation ranging from early to late cleavage. In the cross Tautogolabrus $\circ \times \mathrm{F}$. heteroclitus $\sigma^{7}$ the hybrids are in 8-cell stages when the pure-bred Tautogolabrus are entering upon the 16-cell stage. In the cross Gas- 
terosteus o $\times$ F. heteroclitus $\sigma^{7}$ the hybrid showed a less marked spread of the late segmentation disc than did the pure-bred embryos. Many other cases are cited that show evident retardation during gastrulation.

As a rule the earlier the retardation, the more pronounced the developmental block. Hybrids in which the retardation occurs during early cleavages are apt to disintegrate during late cleavage. Those that show no retardation until gastrulation is well under way, are apt to show a considerable degree of developmental success. The probable cause of early retardation is abnormal cleavage. The Hertwigs and Miss Morris show clearly that decidedly irregular cleavages occur in hybrid blastodises. This disruption of the normal process could not but result in retardation. It is also probable that later retardation is based on later irregularities in cleavages, for, in many of the crosses described in this paper, it was noted that the cell structure of certain regions is abnormally coarse, the cells being of uneven size and many of them of giant size. Such a condition indicates some abnormality in the cleavage mechanism.

It is remarkable, as Appellöf first pointed out, that the most frequent stopping place in the development of heterogenic hybrids is at the end of the cleavage period, or just before the onset of gastrulation. Since gastrulation is essentially a phenomenon of differentiation it is not surprising that we should find so many heterogenic crosses blocked at this point. For though mere cell multiplication or cleavage might proceed more or less successfully in spite of the irregular distribution of the chromatin, tissue differentiation cannot go forward under such conditions.

The next developmental block is that of embryo formation. Many crosses that enter upon early germ-ring stages without exhibiting any abnormalities come to a stop during middle and late germring stages. It would appear that in such crosses the embryonic axis does not form signifying that concrescence of the two halves of the germ-ring fails to occur; hence the advance of the germring is stopped at various points from one-fourth to three-fourths of the way around the yolk. Sometimes concrescence begins but soon stops. Again an embryonic axis is established but the 
blastopore remains as an oval or slit-like opening. In such cases one of several things may happen. Either the germring retreats to the animal pole of the egg and gathers into a lump-like embryonic mass that may form pigment cells and assume a vague likeness to a short embryo; or a flat embryonic shield with two rings of germ band enclosing an elongated blastopore may continue to live and differentiate regionally for some time; or advanced bodyless heads may develop and appear to end abruptly against a flat sheet of cells derived from the germband; or, finally, advanced embryos with well developed heads may occur at a distance from the posterior parts of the body separated from the latter by a flat germ-band region. All of these abnormalities are to be attributed to various interruptions of the process of concrescence. The beginning of gastrulation is the most general block in hybrid development but concrescence is scarcely less important. The cause of the latter block is not known, but is probably associated with the general retardation of development. The less energetic overgrowth of the yolk by the blastoderm is doubtless accompanied by a lowered fusion energy so that the two halves of the germ-ring do not so strongly attract each other. Many types of hybrid have no difficulty with gastrulation until the very last stage of blastopore closure. Such embryos develop for the most part normally, but show various defects of the tail region, where the metabolic rate is lowest, such as short tail or bent and spiral forms.

As a rule, hybrids that successfully weather the vicissitudes of gastrulation and are normal after the closure of the blastopore meet no distinct developmental block until the time comes for circulation to be established. It is very common for certain types of hybrids to go forward to advanced stages in which head and body are normally differentiated, in which the heart is formed and pulsating, but in which blood fails to develop and thus circulation is not established. The lack of a circulation at certain critical stages hinders, though it does not necessarily prevent, yolk assimilation, and various well defined organic disturbances result. The most frequent consequence of a failure to establish a circulation is seen in those types of hybrids in which the heart 
is stretched out across the yolk in an enlarged pericardium. The heart beats but carries no blood. In other cases blood is formed but in such small amounts that symptoms of anemia soon appear and death ensues. If a full circulation is established the embryo has a good chance to hatch and to live as a normal larva but many cases have been cited in which embryos with circulation apparently normal have failed to hatch. It may be that in these cases the circulation was established too late in the developmental history and that it is not possible for the belated embryo to regain the lost ground.

It is quite common to find certain types of embryos that die shortly after hatching. As yet I have been unable to understand the low viability of these types. There are, however, here described many hybrid forms that hatch and seem to be normally viable, and I see no reason to doubt that these could be reared to advanced stages.

Practically all the well defined abnormalities and monsters of various sorts are, I believe, the result of a retardation of certain processes, chief among which is the process of concrescence. Cyclopia is doubtless, as Stockard has shown, due to a failure to separate on the part of the median ventral optic primordia of the brain floor. Double headed monsters are a result of a failure to concresce of the anterior germ-band, and spina bifida, double tail and similar abnormalities are likewise results of incomplete concrescence.

It is generally the case for heterogenic hybrids that in any strain some individuals surmount the developmental blocks that effectively stop others. In nearly all of the crosses described it has been noted that a considerable per cent of the hybrids cease to develop at the end of cleavage or during gastrulation, some may be blocked at the point of blood formation and others go on to hatching. What explanation can be offered for such a wide variation among embryos of common parentage? This same inquiry was made by Appellöf many years ago and the answer was deferred by him until such time as he should be able to conduct a more extensive series of researches on Teleost hybrids. I have what seems to me to be an adequate 
mass of data bearing on this question but am still unable to give any satisfactory solution of the problem. It may, however, be suggested that the differences in success may be due to physiological differences in the condition of the egg and sperm, for it is probable that in any large number of germ-cells forcibly stripped from males or females some of each kind will be in better condition for development than others.

All the developmental blocks herewith cited are looked upon as developmental crises during which embryos are especially susceptible to disturbances introduced by a lowered metabolic rhythm. These crises probably represent the apices of curves of morphogenetic activity when the metabolic rhythm is at its height. The normal changes associated with these crises occur successfully only when the tonus of the rhythm is sustained at its proper level. A lowering of the tonus produces abnormalities. Any processes requiring less developmental pressure or a lower tonus go on irrespective of these blocks as we shall see in the next section.

\section{Auto-differentiation and de-differentiation}

It is not without interest in connection with these hybrid experiments to note certain phenomena of embryonic differentiation and de-differentiation, which are not specifically hybridization effects, but are merely the secondary result of abnormal conditions brought on through the disharmony of foreign germ plasms. In many of the experiments attention was called to the high degree of independence exhibited by certain types of cells and tissues. Chromatophores, for example, which normally appear only after considerable embryonic differentiation has occurred, develop and go to the definitive stages even when no other tissues may be differentiated. In those cases where the germ-ring retreats and forms a lump of tissue at the animal pole it often happens that such a formless embryonic mass becomes pigmented with the characteristic chromatophores of the species. Chromatophores can usually be relied upon to go their course and reach a definitive condition even when em- 
bryonic differentiation stops at an early period. This result is taken to mean that chromatophores belong to a type of cells that are remarkably independent and are not closely correlated with the more highly organized tissues. They wander about and locate themselves in places of advantage. If no circulation is established they creep upon the beating heart, which never happens in normal embryos. When blood vessels form but no blood is developed chromatophores still gather about the blood vessels. This formation of vessels independent of blood is another illustration of tissue independence; but the most striking case of this sort is met with in those forms that develop a heart that continues to function even without a blood content. As I have noted repeatedly above, hearts of this sort are from the very first stretched out over the yolk so that they are under considerable tension. Yet they undergo the same flexures as when they are crowded within a restricted pericardium. It is commonly believed that the heart flexures are the result of a reaction of the heart to a restricted space, but when a stretched heart develops the same flexures this explanation becomes quite inadequate. It was noted also that hearts occasionally become entirely separated from the body of the embryo but, in spite of this isolation, they beat rhythmically, indicating that the heart itself is the seat of its own automaticity. It is in fact highly probable that such tissue is without ganglion cells and that the heart rhythm is therefore myogenic. Again it is often noted that even though the body may fail to cut itself off from the yolk, fins may develop out on the blastoderm that is still spread over the yolk. Such limb-buds may differentiate until they are capable of independent movement.

All these phenomena impress one with the idea that the embryo is less of a unit than we had supposed, that many semiindependent processes are at work to produce a harmonious end result and that one process may frequently be inhibited without interfering seriously with the others. It also appears that the particular fate of a region is determined rather early and that radically changed environmental factors fail materially to alter the end result. 
While differentiation of certain parts goes on without hindrance other parts may be de-differentiating. Many cases are noted in which, without the general death of the embryo, certain regions that have reached an advanced stage of differentiation cease to develop and begin to lose their definition. This is seen most distinctly in connection with the head and particularly with the eyes. In some crosses the eyes and other special organs of the head develop normally to an advanced stage and then begin to grow vague. This appears to mean that the tissues are returning to a generalized state. They are not dead as is evident by the retention of their transparency, for dead tissue becomes more or less opaque. Heads diminish in size; pigment on the eyes migrates to other regions and the details of eye structure are lost. Such de-differentiated embryos may live for weeks and may continue to develop structures at a distance from the head end. In some cases de-differentiation involves only the most anterior regions of the head including the eyes. When the eyes are de-differentiated the otic vesicles become the dominant regions of the head and grow to unusual size. This would appear to mean that the eyes are the controlling elements of the head and that when they disappear the control or dominance passes back to the next elements, the otic vesicles. The student of developmental mechanies would find much to interest him in these cases and would probably discover many others equally significant.

\section{SUMMARY}

1. Ninety-three crosses among fourteen species of Woods Hole Teleosts were made and of these seventy-eight are heterogenic and are here dealt with. The homogenic crosses are to be treated separately.

2. Heterogenic crosses are those between different orders or families; homogenic crosses are between different genera of a family or between different species of a genus.

3. In seventeen heterogenic crosses some embryos established a circulation and in sixteen larvae were hatched.

4. There is as much developmental success among the heterogenic as among some homogenic crosses. In general there 
seems to be no primary correlation between the degree of success in development and the nearness of relationship of the species crossed.

5. The factors determining the relative success in development of hybrids are associated with the amount, density and specific composition of the yolk, and with hardiness of the egg.

6. The factor of rate of development appears to be a mere secondary factor in the success of hybrids as species with a slow development cross readily with rapidly developing species.

7. The differences in developmental success of reciprocal crosses are due to the same factors that lie at the basis of hybrid success in general. The hybrid from the species of egg that is more adaptable to hybridization will, irrespective of phylogenetic relationship, develop more successfully than the reciprocal cross from the less adaptable species of egg.

8. Many cases are cited in which definite paternal characters are inherited by heterogenic hybrids, which goes to disprove Loeb's conclusion that heterogenic hybrids are pure maternal and that the sperm plays only the rôle of initiating development, without having any share in embryo formation or heredity.

9. In all the crosses in which some embryos develop to hatching the most successful of them are predominantly maternal; but less successful hybrids show both maternal and paternal influence in varying degrees. The nearly pure maternal larvae are thought to be merely phenotypically so, for it is likely that this germ-plasm carries its full quota of paternal inheritance factors.

10. All of the well known types of monsters occur in hybrid strains. These abnormal conditions are in some cases specific for certain crosses and others are of a more generalized character occurring in many crosses. All of the abnormal types are capable of being interpreted as retardation products and therefore as due to the slowing down of development through the disharmonious interaction of foreign germ plasms.

11. The principal developmental blocks noted in heterogenic hybrids occur in connection with the following crises: gastrulation, concrescence, head differentiation, the establishment of a cir- 
culation. These crises probably represent the apices of curves of morphogenetic activity, when the metabolic rhythm is at its height. A lowering of the rate of metabolism affects these processes more profoundly than it would processes associated with a low developmental tonus.

12. Many cases of independently differentiating tissues are cited, chief among which are chromatophores, heart, fins, etc. These structures continue to develop when isolated from their normal environment. De-differentiation of the more highly differentiated parts occurs readily even while the less differentiated parts continue to grow. General death occurs slowly and some tissues are particularly resistant. Chromatophores go on to their definitive state even when the tissues of the embryonic body are reduced to a generalized mass of cells.

\section{BIBLIOGRAPHY}

APPELlöF, A. 1894 Ueber einige Resultate der Kreuzungsbefruchtung be Knochenfischen. Bergens Museums Aarbog, No. 1, pp. 1-19.

BaNCROFT, F. W. 1912 Heredity of pigmentation in Fundulus hybrids. Jour. Exp. Zoöl., vol. 12, no. 2, pp. 153-178.

Hertwig, G. und P. 1914 Krenzungsversuche an Knochenfischen. Arch. f. mikrosk. Anat., Bd. 84, abt. 2, pp. 49-88.

Lоeв, J. 1912 Heredity in heterogeneous hybrids. Jour. Morph., vol. 23, no. 1, pp. 1-16.

Moenkhaus, W. J. 1894 The development of hybrids between Fundulus heteroclitus and Menidia notata, with especial reference to the behavior of maternal and paternal chromatin. Am. Jour. Anat., vol. 3, pp. 29-65.

1910 Cross fertilization among fishes. Proc. Indiana Acad. Sciences, pp. 353-393.

Morris, M. 1914 The behavior of chromatin in Teleost hybrids. Jour. Exp. Zoöl., vol. 16, no. 4 .

Newman, H. H. 1907 Spawning behavior and sexual dimorphism in Fundulus heteroclitus and allied fishes. Biol. Bull., vol. 12, pp. 314-349. 1908 The process of heredity as exhibited by the development of Fundulus hybrids. Jour. Exp. Zoöl., vol. 5, no. 4, pp. 503-511.

1910 Further studies of the process of heredity in Fundulus hybrids. Jour. Exp. Zoöl., vol. 8, pp. 143-162.

1911 Reply to E. Godlewski's "Bemerkungen zu der Arbeit von H. H. Newman; 'Further studies of the process of heredity in Fundulus hybrids." " Arch. f.' Entw-mech., Bd. 32, pp. 472-476.

1914 Modes of inheritance in Teleost hybrids. Jour. Exp. Zoül., vol. 16, no. 4 , pp. $447-499$. 